\title{
Comparative Life Cycle Assessment of Mobile Power Banks with Lithium-Ion Battery and Lithium-Ion Polymer Battery
}

\author{
Jie Yang ${ }^{1}$, Fu Gu ${ }^{1,2, *}$, Jianfeng Guo ${ }^{3,4}$ and Bin Chen ${ }^{5}$ \\ 1 Department of Industrial Engineering, Zhejiang University, Hangzhou 310027, China; 11625076@zju.edu.cn \\ 2 National Institute of Innovation Management, Zhejiang University, Hangzhou 310027, China \\ 3 Institutes of Science and Development, Chinese Academy of Sciences, Beijing 100190, China; \\ guojf@casipm.ac.cn \\ 4 School of Public Policy and Management, University of Chinese Academy of Sciences, Beijing 100049, China \\ 5 State Key Joint Laboratory of Environmental Simulation and Pollution Control, School of Environment, \\ Beijing Normal University, Beijing 100875, China; chenb@bnu.edu.cn \\ * Correspondence: gufu@zju.edu.cn
}

Received: 14 August 2019; Accepted: 16 September 2019; Published: 20 September 2019

\begin{abstract}
Mobile power bank (MPB) is an emerging consumer electronic that stores and delivers electricity to other electronics. Nowadays, MPBs are produced and discarded in massive quantities, yet their environmental impacts have never been quantitatively evaluated. Employing a life cycle assessment (LCA) approach, this study assesses the life cycle environmental impacts of MPBs, with a specific focus on comparing the environmental performance of different MPBs that are based on two types of batteries, namely, lithium-ion battery (LIB) and lithium-ion polymer battery (LIPB). The results suggest that battery production is the greatest contributor to the environmental impacts of both MPBs. LIPB based MPB is environmentally friendlier due to its higher energy density and longer cycle life. In addition, it is found that recycling can reduce the environmental burden of MPB industry as well as ease the vast depletion of metals such as cobalt and copper. The sensitivity analysis shows that figuring out an optimal retirement point and using less carbon-intensive electricity can reduce the climate change potential of MPBs. This study provides recommendations to further improve the environmental performance of $\mathrm{MPB}$, including the usage of more sustainable cathode materials, market promoting direction, and formulation of end-of-life management policy.
\end{abstract}

Keywords: life cycle assessment; environmental impact; metal depletion; mobile power bank; lithium-ion battery; lithium-ion polymer battery

\section{Introduction}

Due to rapid technological developments and socio-psychological needs, new generations of consumer electronics (CE), such as smart wearables and smart phones, are being commercialized and popularized at an unprecedented speed. Ubiquitous use of $C E$ triggers an increasing demand on portable power sources. Consequently, mobile power bank (MPB) or portable power bank, a new type of CE, has emerged and been widely adopted. In essence, MPB is a portable charger that stores and supplies electric energy to a wide range of $\mathrm{CE}$, including mobile phones, tablet computers, smart wearables, and even laptops. During past years, the MPB market has grown steadily and rapidly. By the end of 2017, the MPB market in China alone has reached $\$ 4.53$ billion dollar [1]. Owning to high energy density, light weight, long lifespan, and low self-discharging rate [2,3], most of the MPBs use lithium-based batteries. In most cases, two types of batteries are used in MPBs, namely lithium-ion batteries (LIBs) and lithium-ion polymer batteries (LIPBs). 
The vast production and consumption of MPBs have introduced a series of new challenges to environmental and resource management, and their mitigation requires intensive efforts. Firstly, the rapid technological advances result in massive production of new MPBs and quick obsolescence of previous models. The average lifespan of MPB is reported to be less than two years [4]. Consequently, spent MPB has become one of the fastest-growing global waste electrical and electronic equipment (WEEE) streams, its emissions, wastes, and pollutions associated could be enormous, and its impacts on environment, human health, and resource sustainability can no longer be ignored. Secondly, when compared to LIB, LIPB is considered as an important progress in the development of lithium-ion battery due to a higher level of safety, better electrochemical stability, and a lower life cycle degradation rate [5,6], formation ability, and flexibility [7]. However, whether LIPB is more environmental than LIB remains unknown, as these two types of batteries are seldom compared in terms of environmental impacts. Thirdly, the natural reserves of metals that are used in batteries, such as lithium and cobalt, are being depleted at an unprecedented speed due to the vast demands from CEs and electric vehicles (EVs) [8]. A proper life cycle management of MPB could be highly important to the sustainable development of these industries. However, to the best of our knowledge, there is little knowledge about the environmental performance of this particular $\mathrm{CE}$, and available data are scattered sporadically on different types of MPB.

In this work, we first model the life cycle of MPB and conduct a material flow analysis (MFA) to acquire the information of material usage. Based on the life cycle model and aggregated inventory data, a life cycle assessment (LCA) approach is applied with specific attention paid to identifying the differences in the environmental performance of MPB based on two types of batteries, i.e., LIB and LIPB. LCA is an effective technique and has been widely used in many types of CEs such as personal computers and mobile phones $[9,10]$ as well as their components like battery and PCB $[2,11,12]$. A sensitivity analysis is carried out to identify key parameters, including the cycle life, the discharging efficiency of MPB, and the sources of electricity consumed during the life cycle of MPB. In addition, the resource depletion is analyzed with consideration of lithium, cobalt, and copper. Further, implications are provided in three aspects, including selection of materials and technologies, market promoting strategy, and formulation of end-of-life (EoL) management, with the purpose of reducing the overall environmental burdens of MPB.

We have been making great efforts to dig out MPB's environmental potentials, aiming to cope with the huge and increasing numbers of MPBs produced in China. The contribution of this work is threefold. Firstly, a complete Life Cycle Inventory (LCI) data of MPB is aggregated to evaluate its life cycle environmental performance, in which influential materials and processes are identified. Secondly, the life cycle environmental impacts of two types of MPBs based on different batteries are compared, providing quantitative evidence to support the decisions on MPB development. Thirdly, this study analyses the depletion of metals such as lithium, cobalt, and copper in the MPB industry, and the environmental benefits of metal recycling are further identified. The results will improve our understanding of the environmental performance of $\mathrm{MPB}$, being useful for stakeholders to improve life cycle management of MPB with the purpose of meeting increasingly stringent environmental legislative requirements like Extended Producer Responsibility (EPR) [13].

\section{Methods}

In this study, a LCA approach, a common tool that quantifies the environmental performance of certain products $[14,15]$, is employed. According to the related International Standard Organization (ISO) 14040 standard [16], the LCA methodology is applied in all its four basic stages: goal and scope definition, inventory analysis, impact assessment, and interpretation.

\subsection{Goal and Scope}

The primary goals of the LCA methodology include: 
(i) To evaluate the life cycle environmental impacts of the MPB model and identify influential materials and processes from cradle to grave.

(ii) To compare the environmental performance of the LIB based MPB and LIPB based MPB and analyze causes of the differences.

\subsubsection{Functional Unit}

Functional unit (FU) is defined as the quantified performance of a product system for use as a reference unit [16], providing a functionally equivalent basis that makes the comparison of several products or systems feasible [17]. As the service provided by MPB is electricity storage and delivery, the FU is set to one watt-hour of electricity delivery $(1 \mathrm{Wh})$. This is because the primary differences of MPBs lie in the battery types, energy densities, cycle lives, and efficiencies, and these parameters greatly affect the amount of electricity stored and delivered during MPB's life cycle $[18,19]$. This FU has been widely used in LCA of vehicle batteries and energy storage systems (ESSs) [20,21].

To provide a holistic view of the available MPB models on the market, we did a survey on the parameters of fifty best-selling MPB models in the Chinese market that ranked on JD (www.jd.com), a popular online mall which has 292.5 million annual active customer accounts in 2017 [22]. The detailed parameter information of these models is presented in Table A1 of the Appendix A, and the statistical results are shown in Figure 1. According to the survey results, we take two popular types of MPBs on the market as our research objects, i.e., a LIB based MPB with nominal capacity of $37.44 \mathrm{Wh}$ (3.6 V/10,400 mAh) and a LIPB based MPB with nominal capacity of $37 \mathrm{Wh}(3.7 \mathrm{~V} / 10,000 \mathrm{mAh})$.

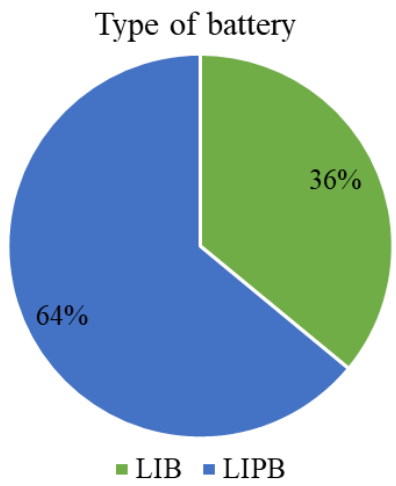

(a)

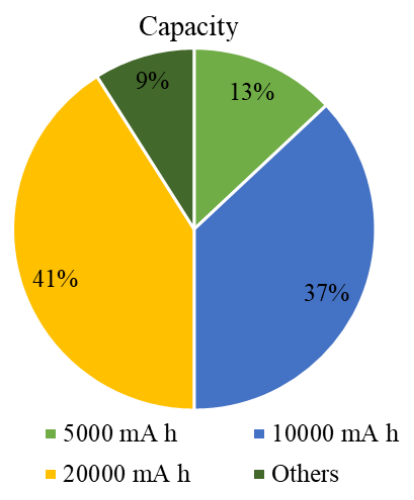

(b)

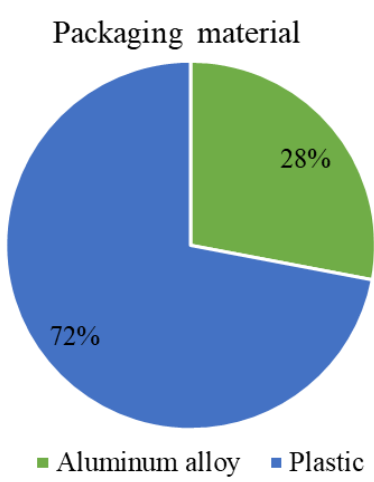

(c)

Figure 1. Specific proportions of mobile power bank (MPB) (a) Types of batteries; (b) Capacity of MPB; (c) Packaging materials.

The selected MPBs in this study contain three modules, i.e., batteries, packaging, and PCB. Battery charger and other components like charging cable, liquid crystal display (LCD), and others are excluded as they are not the essential components and have significant differences due to models.

\subsubsection{System Boundaries}

Figure 2 shows the boundary of the foreground system, which covers the whole life cycle of MPB. The life cycle of MPB can be divided into three phases: (1) production phase, (2) use phase, and (3) recycling phase. The processes included in the life cycle are the extraction of raw materials, the production of the battery cell and its components, the assembly of MPB, the use phase, the delivery of the stored electricity, the transportation, and the final disposal process as well. Since little is known about recycling of MPB, this study proposes an ideal recycling model, as its three main components are all supposed to be recycled. 


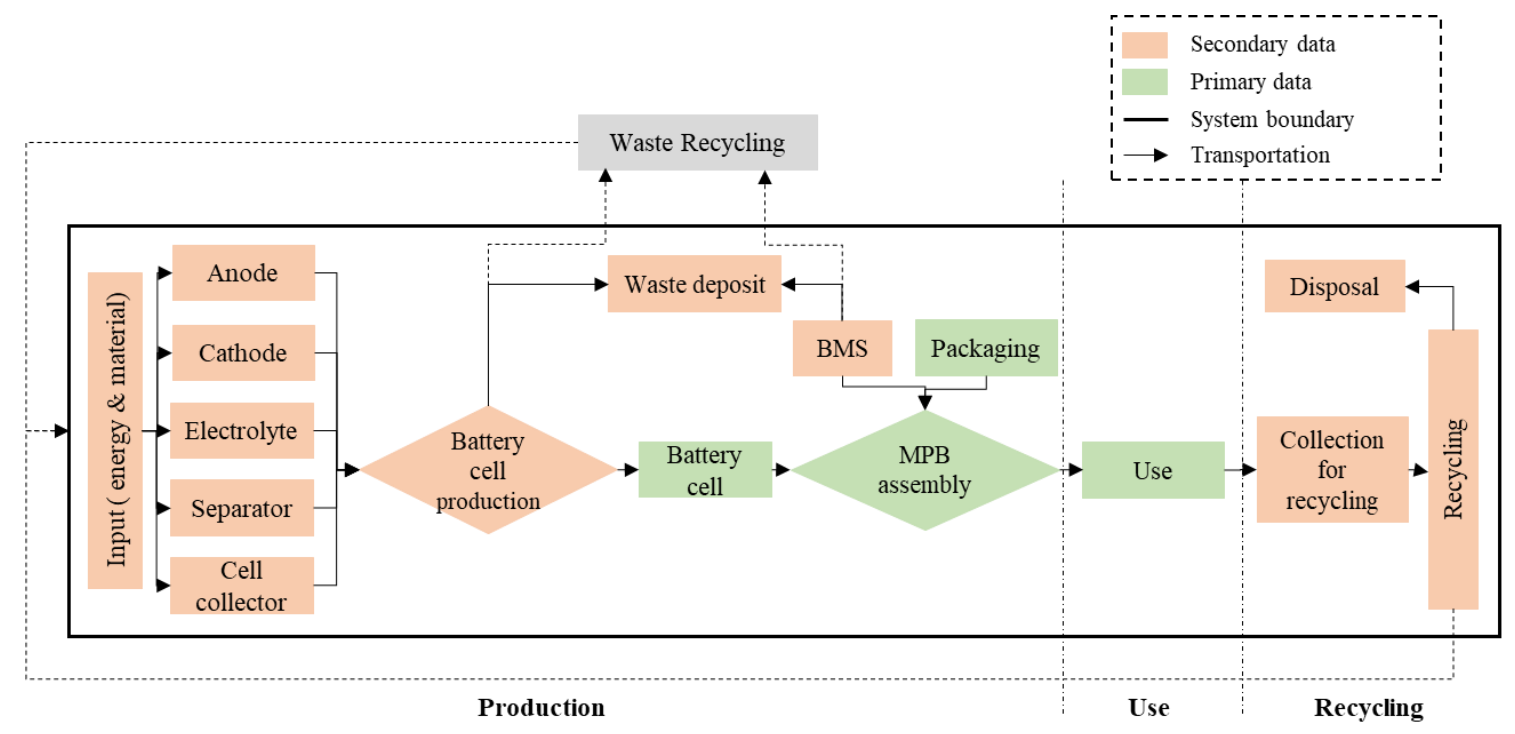

Figure 2. System boundary of MPB model.

\subsection{Life Cycle Inventory}

This section aims to present all the data and assumptions considered for all relevant processes in the MPB life cycle. The data used in this study are divided into primary data and secondary data, and Figure 2 presents the data types of each process of MPB. The primary data, including MPB module composition and the weight of each module, are obtained by manually dismantling and weighing, and the charging and discharging efficiency of MPB are obtained through charging and discharging MPBs in various states. Nevertheless, due to the commercial confidentiality, detailed inventory data of components like LIBs and PCBs are always in short supply [19]. With reference to relevant study in this field, secondary data from several classic publications [23-25] and manufacturer's guidance are employed. Table 1 summarizes the characteristics of the two types of MPB models, and a detailed LCI built for the two types of MPB models is further collected and compiled in Table A2 of the Appendix A.

Table 1. MPB characteristics.

\begin{tabular}{cccc}
\hline Parameter & LIB Based MPB & LIPB Based MPB & Source of Information \\
\hline $\begin{array}{c}\text { Battery material } \\
\text { composition }\end{array}$ & NMC/C & NMC/C & Based on [23-25] \\
\hline $\begin{array}{c}\text { MPB module } \\
\text { composition }\end{array}$ & $\begin{array}{c}\text { LIBs, PCB and metal } \\
\text { packaging }\end{array}$ & $\begin{array}{c}\text { LIPBs, PCB and metal } \\
\text { packaging }\end{array}$ & Primary data \\
\hline Nominal capacity (Wh) & 37.44 & 37 & Manufacturer's guidance \\
\hline Number of cells per MPB & 4 & 2 & Primary data \\
\hline Cycle life (times) & 300 & 500 & Manufacturer's guidance \\
\hline $\begin{array}{c}\text { Charging/Discharging } \\
\text { efficiency }\end{array}$ & $82.92 \% / 76.65 \%$ & Primary data \\
\hline $\begin{array}{c}\text { Recycling route } \\
\text { process }\end{array}$ & $\begin{array}{c}\text { Hydrometallurgical } \\
\text { process }\end{array}$ & Based on [26-28]
\end{tabular}

\subsubsection{Production}

The selected two types of MPBs were disassembled and weighed separately to identify the bills of composition, which are shown in Figure 3. In general, both MPBs consist of three modules: battery, printed circuit board (PCB), and packaging, in which battery is the core module responsible for energy storage and release. Moreover, the composition of electrode of the two batteries is essentially the same, 
and the major difference lies in the structure-LIPBs additionally use a polymer material to produce a conductive gel with electrolyte based on the electrolyte of LIBs [29]. Table 2 shows the material compositions and mass ratio of the three modules in MPB.

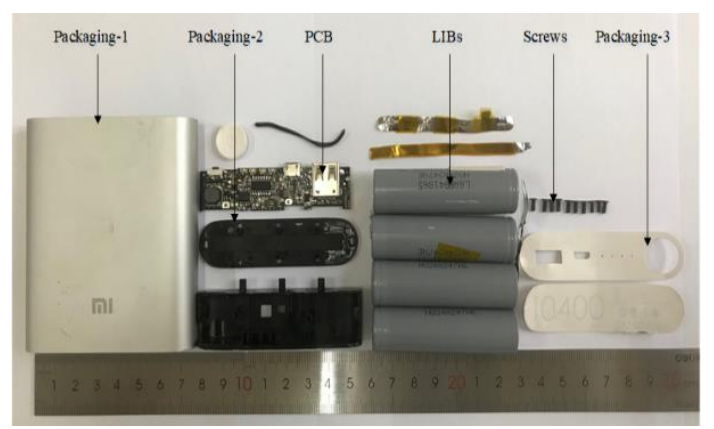

(a)

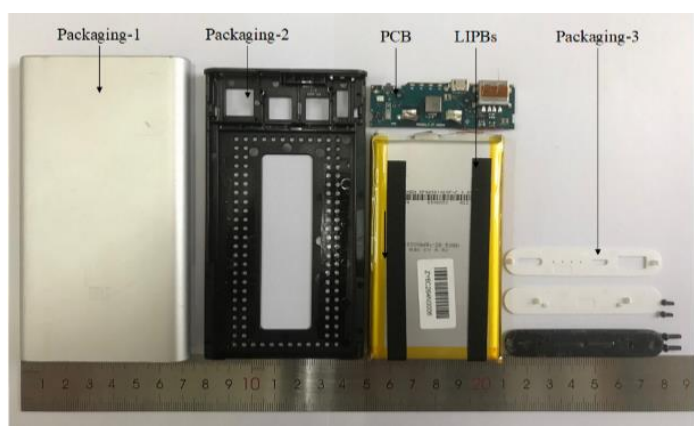

(b)

Figure 3. Components of the two types of MPB: (a) LIB based MPB; (b) LIPB based MPB.

Table 2. Material compositions of two types of MPBs.

\begin{tabular}{cccc}
\hline Component & Material & LIB Based (\%) & LIPB Based (\%) \\
\hline Battery & & 67.76 & 59.16 \\
\hline Cathode & $\mathrm{Li}^{\left(\mathrm{Ni}_{0.4} \mathrm{Co}_{0.2} \mathrm{Mn}_{0.4}\right) \mathrm{O}_{2}}$ & 29.04 & 28.96 \\
\hline Cathode substrate & Aluminum foil & 4.51 & 2.64 \\
\hline Anode & Graphite & 11.76 & 24.17 \\
\hline Anode substrate & Copper foil & 10.38 & 6.13 \\
\hline Electrolyte: salt & $\mathrm{LiPF}_{6}$ & 13.22 & 4.93 \\
\hline \multirow{2}{*}{ Electrolyte: solvent } & Ethylene carbonate & 1.80 & 3.05 \\
& Polycarbonate & - & 0.98 \\
\hline Separator & Polypropylene (PP) & 4.13 & 0.93 \\
& Polyethylene (PE) & - & 0.93 \\
\hline \multirow{2}{*}{ Cell packaging } & Aluminum foil & 25.16 & - \\
& Al-plastic film & - & 27.28 \\
\hline Printed circuit board & & 2.78 & 2.31 \\
\hline Integrated circuit & & 10 & 10 \\
\hline Copper & & 50 & 50 \\
\hline Chromium steel 18/8 & & 40 & 40 \\
\hline Packaging & Aluminum alloy & 29.46 & 38.53 \\
\hline
\end{tabular}

As the core module in MPB, the batteries are responsible for energy storage and delivery. The most commonly-used LIBs in MPBs are 18650 batteries, which consist of five major subcomponents: anode, cathode, separator, electrolyte, and cell container. The detailed schematic of LIB assembly processes and manufacturing processes are given in Figure A1 in the appendix. For LIPB, most of the production processes and materials are as the same as those of LIB, and the main difference lies in the electrolyte: the LIB uses the liquid electrolyte while the LIPB uses the gel polymer electrolyte [29].

PCB plays a decisive role in the energy management of MPB. It can be divided into two parts: boost system and charge management system, which are responsible for managing and monitoring the charging-discharging of MPB and preventing situations of over-charging or over-discharging. According to Majeau-Bettez et al. [24], integrated circuits account for about $10 \mathrm{wt} \%$ of PCB; copper wires are assumed to represent half of the mass, and a stainless-steel container takes the remainder. The packaging of MPB is mainly made of plastic or aluminum alloy, both materials have their own advantages: plastic is lighter, while aluminum alloy is more conducive to heat dissipation and being 
able to absorb more energy shock. According to the manufacturer's guidance, the packaging of both types of MPB in this study is mainly made of aluminum alloy.

Most of the energy consumption and transportation during the manufacturing processes of three modules are considered in this study, except for the energy consumption of MPB assembly, since no data can be found. The detailed data and assumptions of energy consumption and transportation are all compiled into Table A2.

\subsubsection{Use}

The use phase is modeled as the electricity losses from MPB's internal resistance and self-discharging when delivering electricity to CEs. The internal energy efficiency of MPB is supposed to be in the base case including charging and discharging efficiency. Therefore, we performed charging and discharging tests on these two types of MPBs, which are in several different degradation states, and for simplification, we took the average values from the results of the charging and discharging efficiency tests in this study, as has been shown in Table 1.

The life cycle of batteries in the MPB is determined based on observing current rate, state of charge (SOC), operating temperature, and depth of discharge (DoD) [30,31]. For safety purposes and to preserve MPB's life cycle, an $80 \%$ DoD is assumed [32], which means to stop charging the CEs immediately if only $20 \%$ of the nominal capacity remained. In general, the battery degrades over time, and its efficiency fades in association with its capacity and power fading, and the initial life of the MPB is thought to be ended with its batteries. Although this measurement is relatively immature, according to the battery degradation model constructed by Faria et al. [33], the MPB model in this study can still meet the actual discharging capacity of $80 \%$ under the proposed cycle life.

Moreover, due to shortened lifespan and rapid replacement, it is assumed that there is no maintenance activity in the use phase; and as heat is the only direct emission from the use phase, it is assumed that the use of MPB does not have any environmental impacts other than the consumption of electricity. The electricity consumption $\left(E_{u s e}\right.$, in Wh) of the MPB during its use phase can be calculated as follows:

$$
E_{\text {use }}=\left\{\left(1-\eta_{\text {charging }}\right) / \eta_{\text {charging }}+\left(1-\eta_{\text {discharging }}\right)\right\} \cdot C_{n} \cdot D o D \cdot T / 100
$$

where $C_{n}$ is MPB's nominal capacity $(\mathrm{Wh}), \eta_{\text {charging }}$ is the charging efficiency, and $\eta_{\text {discharging }}$ is discharging efficiency; $D o D$ is the depth of discharge of the MPB, and $T$ represents the overall cycle life of MPB based on an $80 \%$ DoD (times).

For both types of MPBs, the charging and discharging efficiency of MPB is assessed through the input/output energy flows of the system, and they can be calculated as:

$$
\begin{gathered}
\eta_{\text {charging }}=C_{n} / E_{\text {in }} \\
\eta_{\text {discharging }}=E_{\text {out }} / C_{n}
\end{gathered}
$$

where $E_{\text {in }}$ is the average amount of electricity entering the MPB (e.g., from the grid) (Wh), and $E_{\text {out }}$ is the average amount of electricity leaving the MPB (e.g., to the CEs) (Wh).

\subsubsection{Recycling}

For recycling, the two types of MPBs are firstly manually disassembled with no environmental burdens. Each part is disposed in separate routes as listed in Table 3. A hydrometallurgical process is employed for the battery recycling, which has been adopted as a major route for battery recycling in China [26], and the cathode materials and copper are recovered [27]. PCBs are shredded mechanically into particles, and then, copper is extracted through a hydrometallurgical route, and the recycling rate of copper is supposed to be $95 \mathrm{wt} \%$. [28,34]. Moreover, it is estimated that about $75 \mathrm{wt} \%$ of aluminum is still in material cycle [35]; a 75\% recycling rate of aluminum alloy is used in this study, and the environmental impact of packaging recovery is quantified with the reduced environmental impact of 
primary aluminum alloy production. Secondary materials are supposed to be used to replace primary materials at a substitution ratio of $1: 1$, as the quality of recycled metallic resources is equivalent to that of pristine ones.

Table 3. Recycling data of different components in LIB based MPB.

\begin{tabular}{|c|c|c|c|c|c|c|}
\hline & \multicolumn{2}{|c|}{ Battery Recycling } & \multicolumn{2}{|c|}{ PCB Recycling } & \multicolumn{2}{|c|}{ Packaging Recycling } \\
\hline & LIB & LIPB & LIB & LIPB & LIB & LIPB \\
\hline Recycling route & \multicolumn{2}{|c|}{ Hydrometallurgical route } & \multicolumn{2}{|c|}{$\begin{array}{l}\text { Mechanically separating \& } \\
\text { hydrometallurgical route }\end{array}$} & \multicolumn{2}{|c|}{$\begin{array}{l}\text { Material recycling } \\
\text { in smelter }\end{array}$} \\
\hline \multicolumn{7}{|c|}{ Energy consumption (kWh/unit) } \\
\hline Electricity & 0.10 & 0.07 & $4.598 \times 10^{-6}$ & $3.211 \times 10^{-6}$ & \multicolumn{2}{|c|}{ - } \\
\hline Natural gas & $2.1 \times 10^{-4}$ & $1.6 \times 10^{-4}$ & \multicolumn{2}{|c|}{ - } & \multicolumn{2}{|c|}{-} \\
\hline \multicolumn{7}{|c|}{ Recovered material (g/unit) } \\
\hline NMC & 46.9 & 34.5 & \multirow{3}{*}{\multicolumn{2}{|c|}{2.5}} & \multicolumn{2}{|c|}{-} \\
\hline Copper & 15.6 & 11.5 & & & \multicolumn{2}{|c|}{-} \\
\hline Aluminum alloy & \multicolumn{2}{|c|}{-} & & & 76.9 & 84.8 \\
\hline Data sources & \multicolumn{2}{|c|}{ Xie et al., [26]; Hao et al., [27] } & \multicolumn{2}{|c|}{$\mathrm{Li}$ and $\mathrm{Xu},[34]$; Ghosh et al., [28] } & \multicolumn{2}{|c|}{ EcoInvent dataset } \\
\hline
\end{tabular}

Considering the whole system boundary of this study includes all of the processes in the MPB's life cycle, detailed material flows can be calculated. MFA is a well-established method for characterizing material flows [32]. Due to the similarity in the structures and compositions of the two types of MPB, we here only quantify the material flows in the overall life cycle of LIB based MPB (Figure 4). We consider input, output, and mass balance indicators, based on the assumption that the average material loss in a single process is $5 \mathrm{wt} \%$ [23]. The dominant input flow is in the battery production, followed by the fabrication of packaging. There is no material input and output during the use phase, and the recycling phase focuses on the recovery of the nickel cobalt manganese lithium-ion (NMC) [26], and copper and aluminum alloy are included in the recycling as well.

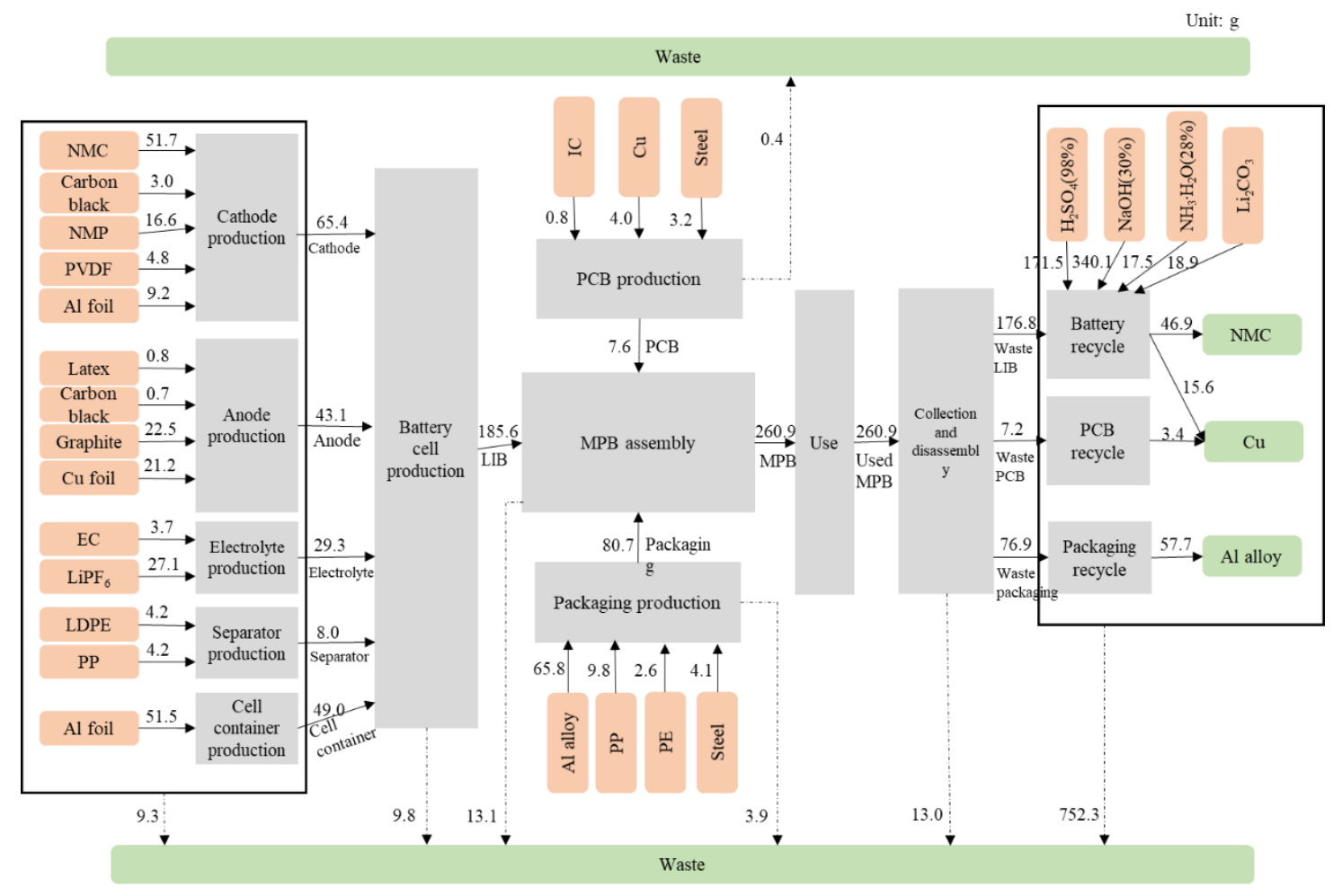

Figure 4. Material flow diagram of life cycle of LIB based MPB. 


\subsection{Impact Assessment}

The life cycle of MPB is modelled by using the software tool GaBi (version 6) with support of EcoInvent 3.3 and Gabi LCI databases. Due to the limited availability of the EcoInvent database, version 1.08 of the ReCiPe method, which has been widely used in the case studies of LIBs [24,36,37], is selected as the method to evaluate the environmental impacts of all life-cycle processes of MPB on the midpoint level. Referring to previous research on assessing the environmental impacts of LIBs [25], the most commonly-used thirteen midpoint impact categories are selected, i.e., climate change (GWP, in $\mathrm{kg} \mathrm{CO} \mathrm{CO}_{2} \mathrm{Eq}$ ), fossil depletion (FDP, in $\mathrm{kg}$ oil Eq), freshwater ecotoxicity (FETP, in kg 1,4-DCB Eq), freshwater eutrophication (FEP, in $\mathrm{kg} \mathrm{P} \mathrm{Eq),} \mathrm{human} \mathrm{toxicity} \mathrm{(HTP,} \mathrm{in} \mathrm{kg}$ 1,4-DCB Eq), marine ecotoxicity (METP, in kg 1,4-DCB Eq), marine eutrophication (MEP, in kg N Eq), metal depletion (MDP, in kg Fe $\mathrm{Eq})$, ozone depletion (ODP, in kg CFC-11 Eq), particulate matter formation (PMFP, in kg PM10 Eq), photochemical oxidant formation (POFP, in $\mathrm{kg}$ NMVOC), terrestrial acidification (TAP, in $\mathrm{kg} \mathrm{SO}_{2} \mathrm{Eq}$ ), terrestrial ecotoxicity (TETP, in kg 1,4-DCB Eq).

\subsection{Sensitivity Analysis}

To define the influence of the variation of critical parameters, a sensitivity analysis is performed including three parameters: cycle life of MPB, discharging efficiency, and the sources of electricity consumed in the MPB's life cycle, among which the first two parameters belong to the internal factor of MPB, while the latter one is the external factor.

(1) Internal factor: According to the previous literature [38], the cycle life and the efficiency varies significantly, and these two parameters are proved to largely affect the energy consumption during the use phase of batteries [39]. To analyze the fluctuations in the environmental impacts to these parameters, two varied scenarios are considered in this study: (a) the lowest and highest values of the cycle life are set to be $50 \%$ and $200 \%$ of the initial value respectively; (b) for the discharging efficiency, the value is assumed with an alteration of 10 percentage points.

(2) External factor: The electricity supplement is required throughout MPB's entire life cycle, and a carbon-intensive electricity mix could result in significant GWP impacts. As one of the world's most carbon-intensive economies [40], China has set mandatory policies to increase the use of renewable energies [41]. In this case, five different electricity sources including coal, Chinese current electricity grid, natural gas, hydro, and nuclear are built into five different scenarios, and how the electricity mix influences the total impact of MPBs is further assessed.

\section{Results}

\subsection{Results of Life Cycle Assessment}

\subsubsection{Overall Life Cycle}

The total life cycle environmental impacts of the two types of MPBs are presented in Figure 5. As shown in Figure 5a, there is a significant difference between environmental impacts of LIPB based MPB and LIPB based MPB. Compared with LIPB based MPB, the calculated environmental impacts of LIB based MPB are averaging 72.5\% larger in categories like FETP, FEP, HTP, METP, MDP, and TETP, while in the rest of the categories, the environmental impacts of LIPB based MPB are less. The values of these categories are closely related to the electricity consumption. 


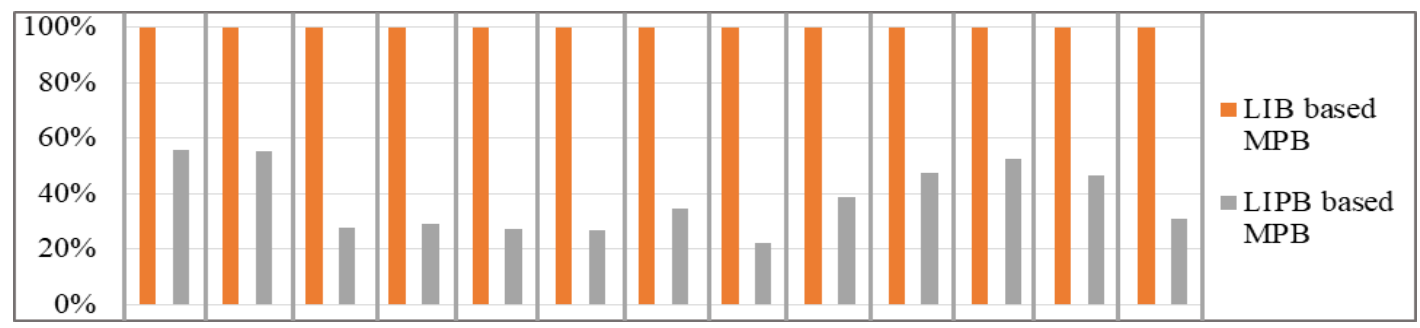

(a) Total values relative to the overall life cycle of MPB with higher impacts.

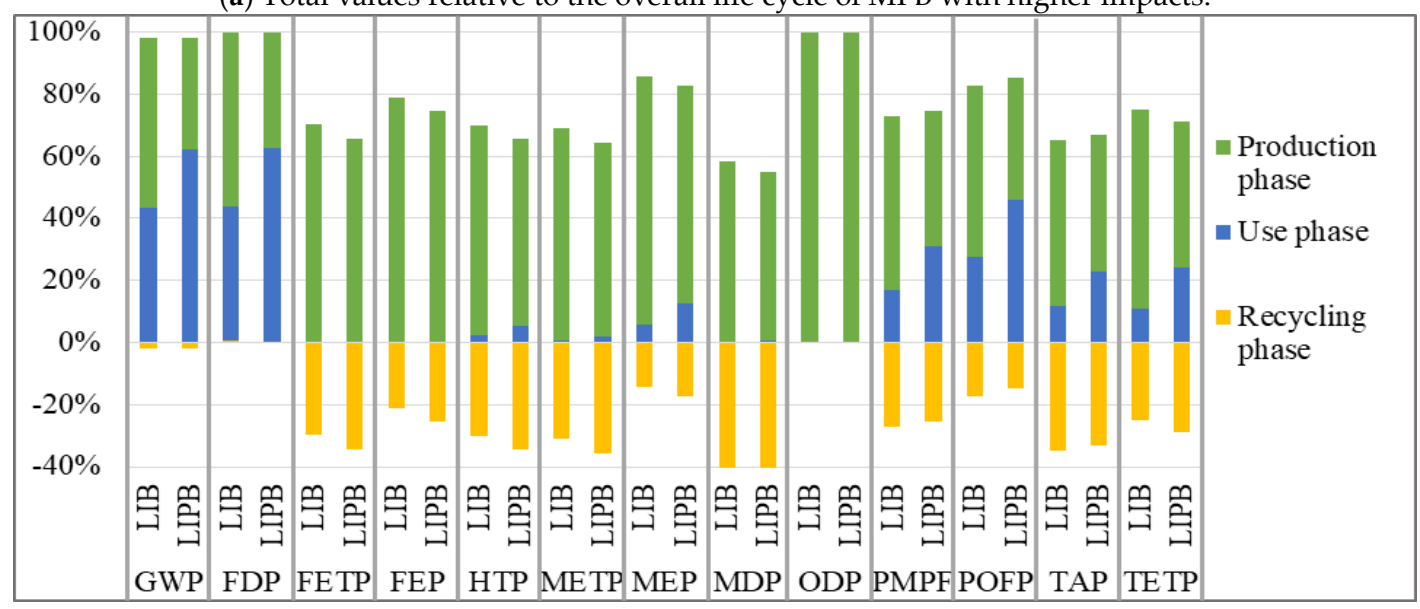

(b) Split into the individual processes that belong to each life cycle of MPB.

Figure 5. Environmental impacts of MPB life cycle for different phases.

Figure $5 \mathrm{~b}$ shows that the life cycle phases of the two types of MPBs have similar contributions to most environmental impacts; both production phases have the greatest environmental impact, with average contributions of $66 \%$ and $61 \%$, respectively. For LIB based MPB, the contribution of the production phase is over $50 \%$ in all the categorized environmental impacts, and the contribution exceeds $66 \%$ in the impact categories like FETP, FEP, HTP, METP, MEP, and MDP. In addition, the use phases of LIB based MPB and LIPB based MPB significantly contribute to the impact categories of GWP and FDP, about $41 \%$ and $58 \%$, respectively. Since electricity consumption is the only source of environmental impacts in the use phase, the environmental burdens in these categories are mainly attributed to the combustion of coal with the Chinese grid power generation [42]. Moreover, the environmental impact of LIPB based MPB is larger than that of LIB based MPB with an average increment of $7 \%$ in the use phase, and this increment can be probably attributed to the longer cycle life of the LIPB based MPB: Through Equation (1), the electric energy consumption of this type of MPB is calculated to be $5.76 \mathrm{kWh}$ throughout its entire cycle life, while the LIB based MPB only consumes $3.94 \mathrm{kWh}$ electricity.

Recycling reduces the environmental impacts of the two types of MPBs by averaging $22 \%$, and the environmental impact of the two types of MPBs are similar. In the recycling phase, the values of the indicators like FETP, HTP, METP, MDP, and TAP are reduced by $31-42 \%$. This observation proves that the production of raw materials outweighs the environmental burdens associated with recycling, particularly in the category of MDP, the value of which is reduced by $42 \%$ due to recycling, as copper and the cathode materials take most of the benefits. The exceptions are the GWP and FDP, as only $1 \%$ reduction in these categorized impacts is observed. As it is evident from Table 3, a great amount of electricity and natural gas are consumed in the hydrometallurgical recycling process of battery, responsible for the significant environmental impacts in the two categories during the recycling phase.

\subsubsection{Production Phase}

As the production phase has the greatest contributions to most of the environmental categories, this phase of two types of MPBs is further analyzed and compared, and the results are shown in 
Figure 6. In Figure 6a, the overall environmental impacts associated with the production of LIB based MPB are significantly greater than those of LIPB based MPB during production, suggesting that the production of a LIPB based MPB could be much more environmentally friendly. The main reason for this finding is that the total mass of LIPB is much smaller than that of LIBs due to its high energy density, as shown in Table 1. Moreover, as the LIPB is expected to enjoy a longer lifetime than LIB, the use phase electricity delivery has a greater relative impact for the former than for the latter; it directly weakens the environmental impacts of the production of LIPB based MPB when normalized for $1 \mathrm{MWh}$ electricity delivery across its life cycle.

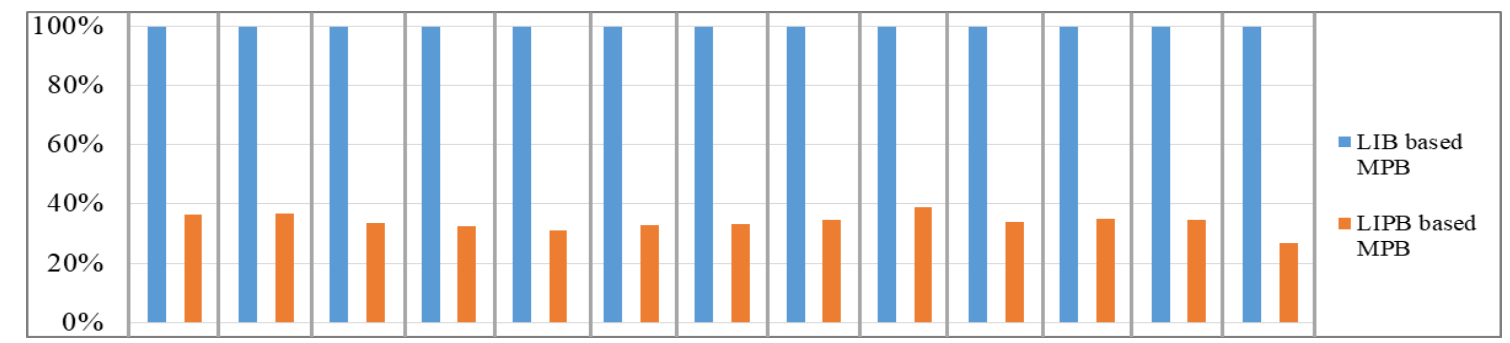

(a) Total values relative to the production of MPB with higher impacts.

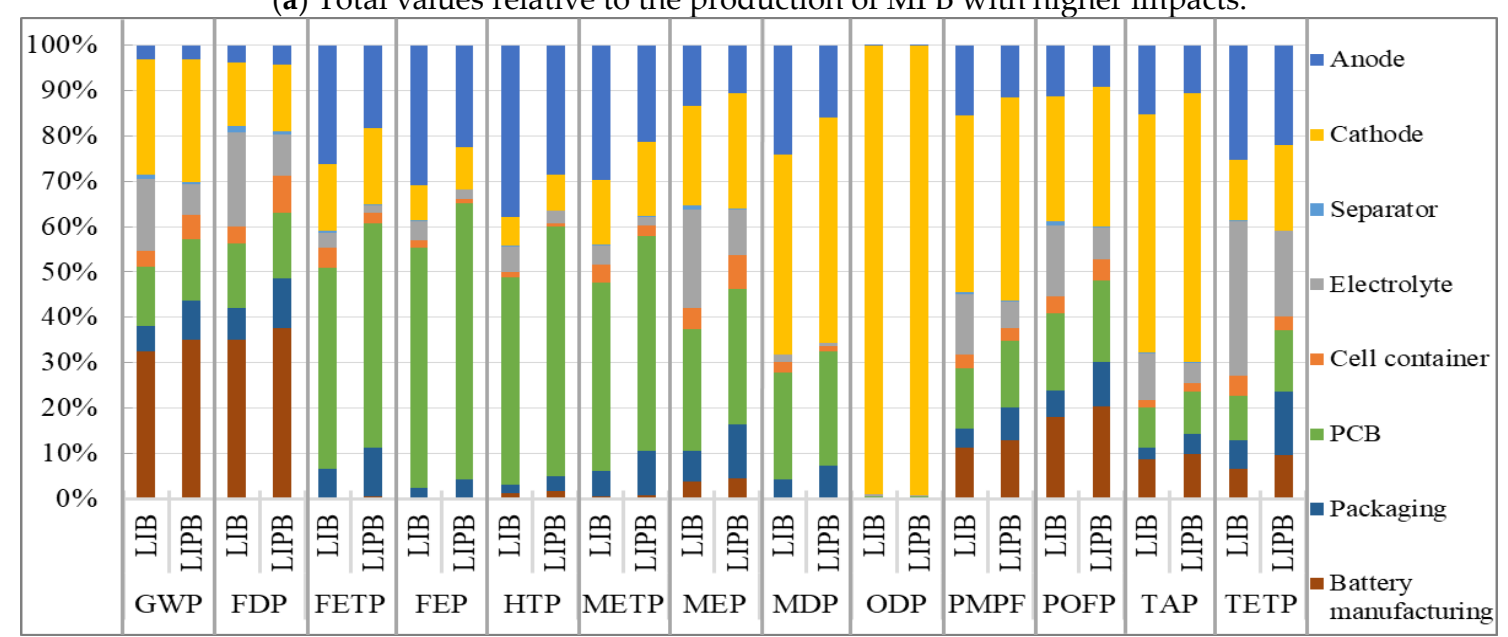

(b) Split into the individual processes that belong to the production of MPB.

Figure 6. Environmental impacts of MPB production phase for different components.

Figure $6 \mathrm{~b}$ shows that the contribution of each component to the total values of the categories is quite similar. In this study, we employ LIB based MPB as an example to illustrate the contributions of the components. During its production phase, the fabrication of cathode contributes over $99 \%$ of the ODP value, mainly resulting from the use of tetrafluoroethylene (TFE); the combination of it and PE is taken as the proxy of PVDF, as suggested in previous literature by McManus [36], and TFE has a high ODP score. The cathode is also the main contributor to the impact categories such as MDP, PMPF, and TAP, around $45 \%$, attributed to the production of NMC. However, it is worth mentioning that the ReCiPe method does not include a depletion characterization factor for lithium, and therefore, the use of lithium has no MDP impact, which, in turn, results in an underestimated MDP value. The fabrication of the anode contributes on average 19\% to the values of most categories except for the category of ODP. An in-depth analysis reveals that the relatively high toxicity impact significantly stems from the copper using negative electrode collector, while the primary copper indirectly causes the disposal of sulfidic tailings [43] that are respectively responsible for $34 \%, 32 \%$, and $42 \%$ of the values of FEP, METP, and HTP, respectively. The fabrication of PCB contributes about $11 \% \sim 29 \%$ for the values of most environmental categories, similar to the anode. The cell container of batteries and the packaging of MPB have minor environmental impacts. 
As for LIPB based MPB, the environmental impacts are on average $66 \%$ smaller than that of LIB based MPB in all of the categories, and the difference between these categories is not noticeable. It should be noted that the anode contributes half share of the differences in these corresponding categorized impacts of MPB, mainly because the LIPB uses much less copper foil in the anode than LIB, the production of which is reported to contribute more than $80 \%$ of the environmental impacts of the categories of FETP, HTP, METP, and TETP during the battery manufacturing [37].

For the categories of GWP and FDP, the battery manufacturing process accounts for around $35 \%$ of both shares. This is attributed to the intensive electricity consumption in the process (i.e., $7.5 \mathrm{kWh} / \mathrm{kg}$ ), among which the electrode drying used to evaporate NMP solvent from the cathode slurry has been identified as the primary contributor. In comparison, Deng et al. estimated an electricity consumption of 11.3-22.8 kWh/kg for the LIB production [44], while other works reported substantial lower electricity consumption within the range of 1-5 MJ/kg [23]; this significant difference is mainly caused by ignoring the dry room facility, which is used to evaporate NMP solvent. Moreover, note that our data does not include the energy requirement of the MPB assembly process, and this would inevitably lead to a lower environmental impact value in the production phase. Figure 7 displays the convergence process of the GWP impact during the overall life cycle of LIB based MPB, intending to capture the major processes of release of $\mathrm{CO}_{2}$ emissions and to identify their contributions.

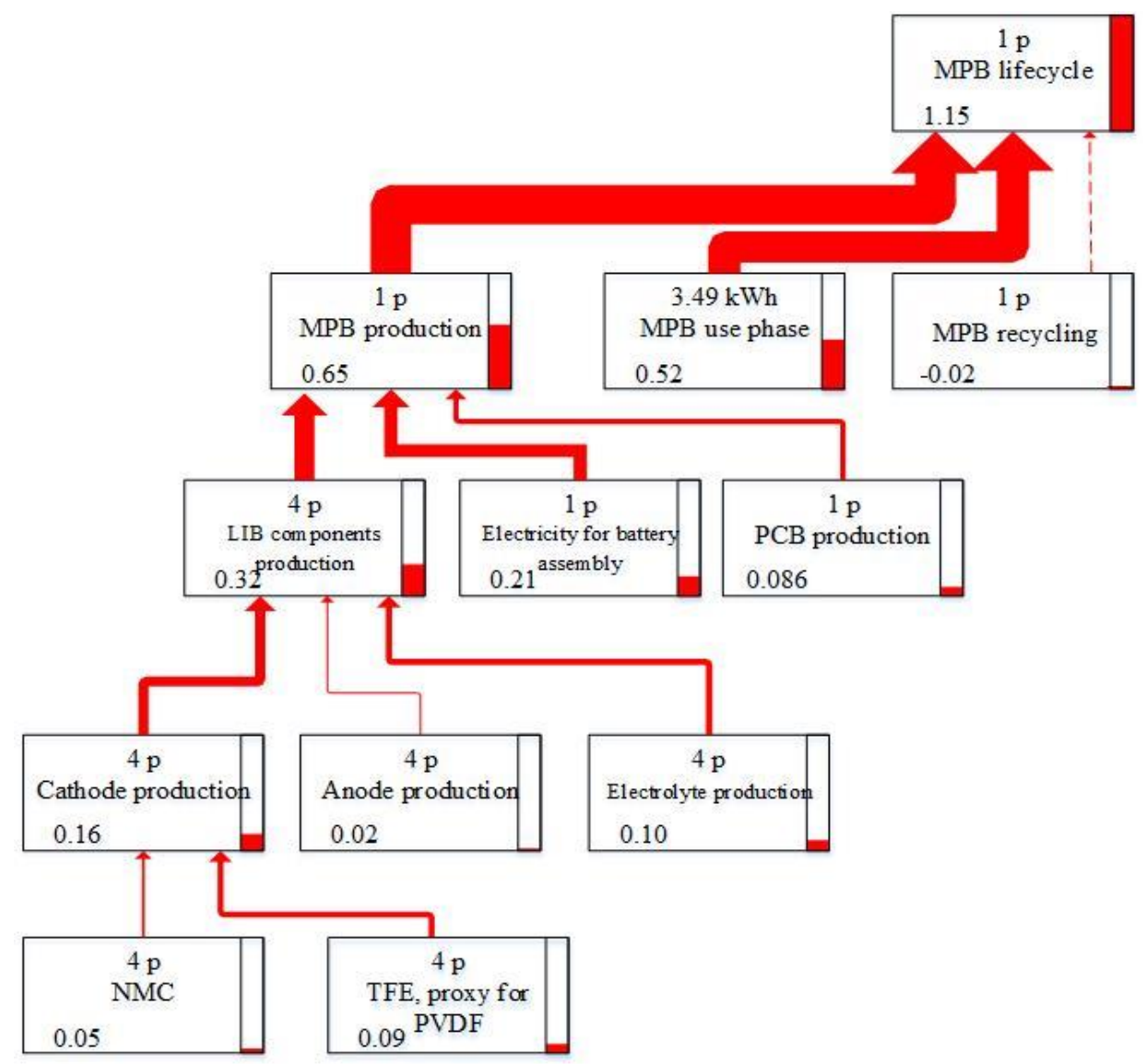

Figure 7. The convergence process of the GWP impact during the overall life cycle of LIB based MPB, the thickness of the arrows and the height of the histograms represent the contribution degree of each process or component.

Figure 7 shows that the three major contributors of GWP are: (1) the electricity consumption in the MPB use phase, (2) battery manufacturing process and (3) the cathode production. More than $40 \%$ of the GWP value stems from electricity usage. The contribution of PCB is noticeable, accounting for almost $21 \%$ of share with only $3 \%$ of the total mass of $\mathrm{MPB}$, and the copper used in it is responsible 
for a large part of the toxicity and ecotoxicity impacts [24]. Production of the cathode and the TFE results in around $23 \%$ of the GWP value, and the production of the electrolyte lead to $24 \%$ of the share. Corresponding to Figure 6, the GWP value of the use phase of LIPB based MPB could be even larger owning to its longer cycle life. Furthermore, the three major contributors also exert significant impacts on the other impact categories, see Figure 6.

\subsubsection{Comparison of Batteries}

The environmental impacts due strictly to the battery production are presented in Figure 8. This figure presents total impacts for two alternative FUs, along with a component-wise allocation of the environmental impacts of battery production. Figure 8a shows that each kilogram of LIB performs relatively worse than LIPB for all impact categories, and in Figure $8 \mathrm{~b}$ this difference is amplified by the larger use phase efficiency of LIPB and the fact that each kilogram of LIPB is supposed to deliver between 3 to 4 times more electricity in its cycle life. Moreover, it could be another reason for a smaller environmental impact of LIPB based MPB production than that of LIB based MPB.

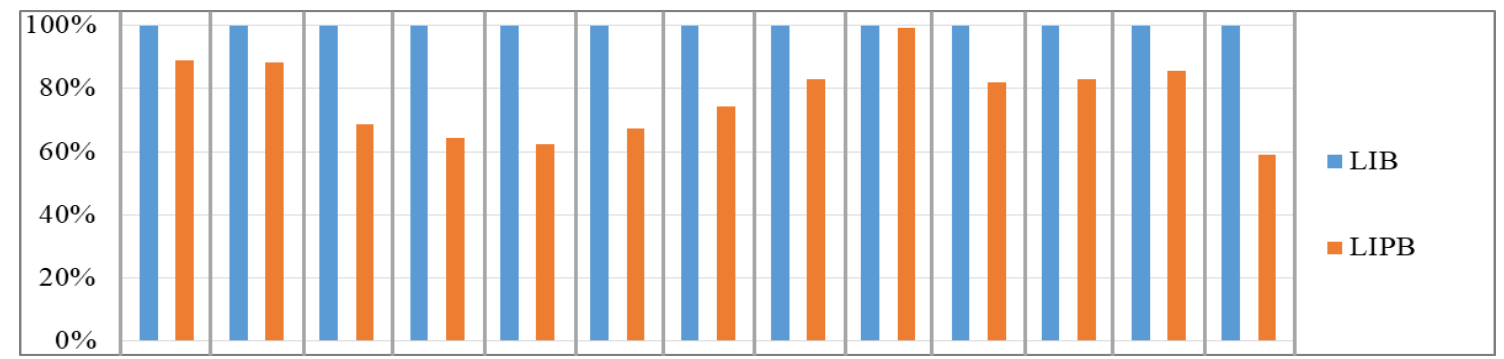

(a) Total values relative to the production of battery with higher impacts (Mass based FU).

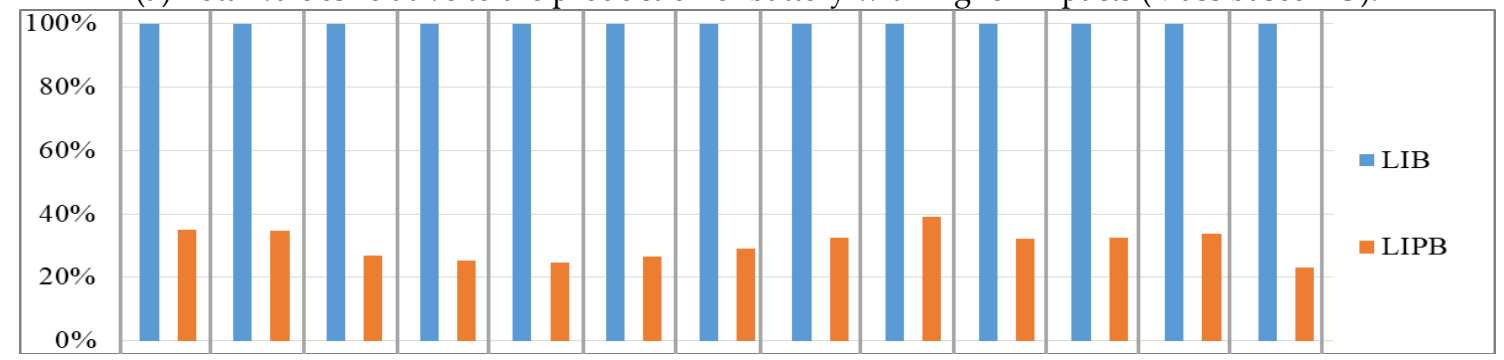

(b) Total values relative to the production of battery with higher impacts (Specified FU).

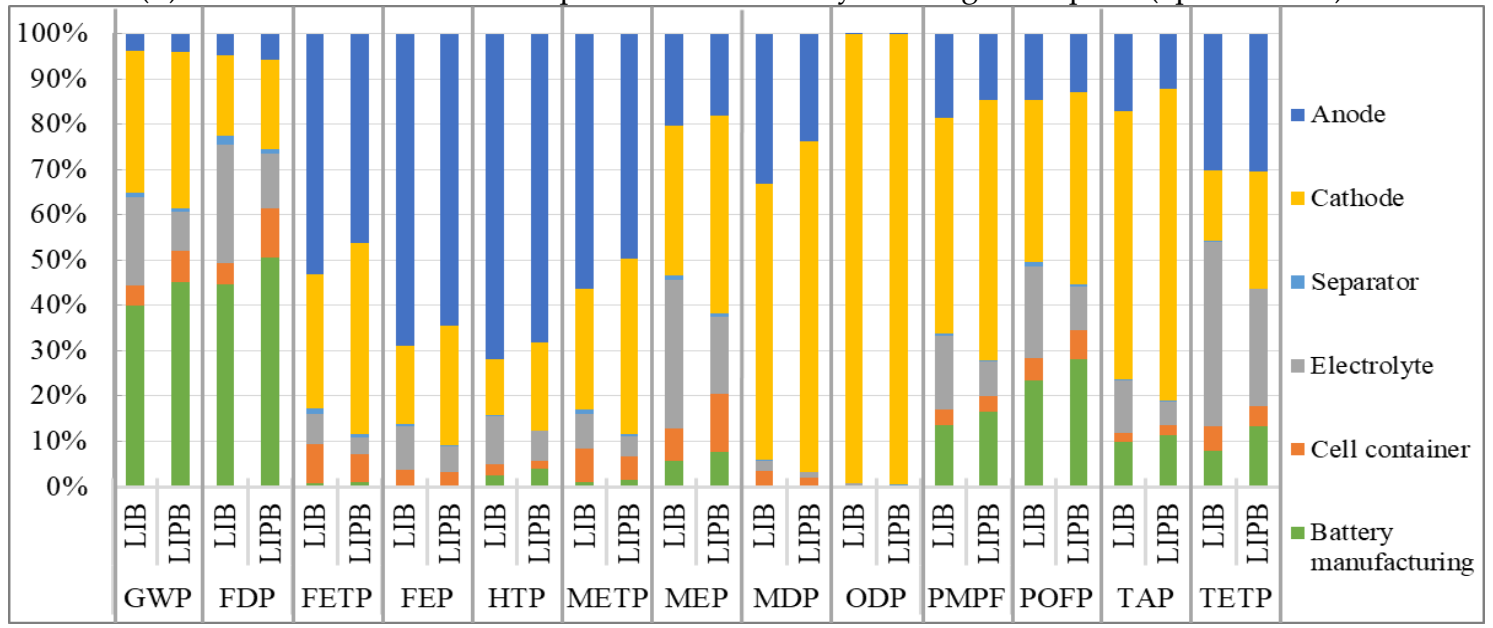

(c) Split into the individual components that belong to the production of battery.

Figure 8. Environmental impacts of the production of LIB and LIPB, reported quantitatively for different functional units. 
The production of the anode and cathode are the two major contributors to most of the categorized environmental impacts. For the anode production, the contribution of LIB based MPB is noticeably larger than that of LIPB based MPB in most of the environmental categories, such as FETP, FEP, HTP, and MDP. While the materials used to produce the anodes in LIB and LIPB are the same, the most noticeable difference lies in the mass ratio of copper foil negative electrode collector. The lower mass ratio of copper foil in LIPB results in smaller impacts. In addition, electrolyte is the major material difference between LIB and LIPB, and its environmental impact mainly varies in categories of GWP, FDP, MEP, POFP, and TETP with an average difference of $13 \%$, attributed to the different lithium hexafluorophosphate contents.

\subsection{Results of Sensitivity Analysis}

In this study, a sensitivity analysis is performed in Figure 9.

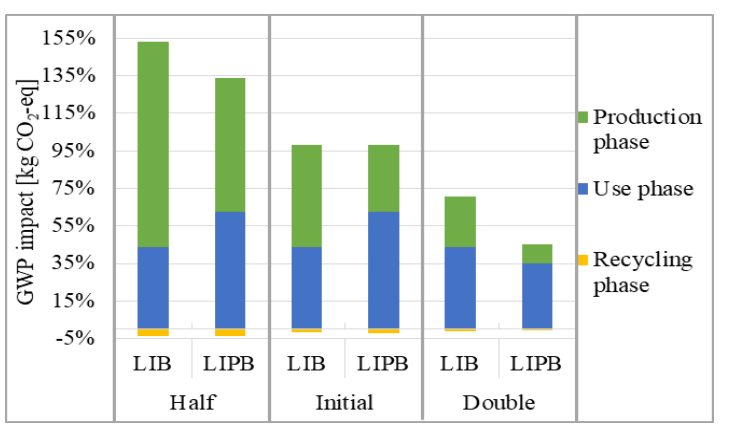

(a)

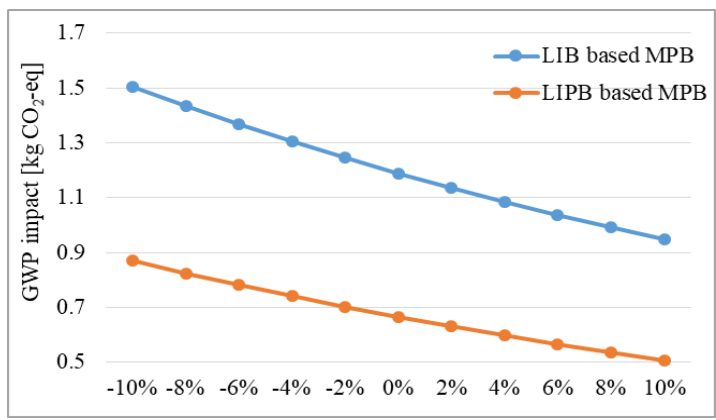

(b)

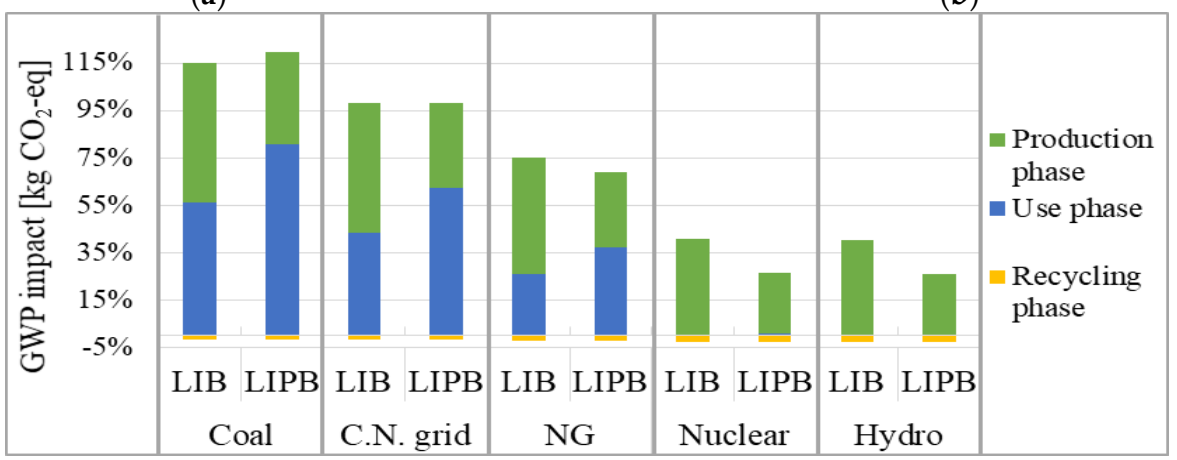

(c)

Figure 9. Sensitivity analysis with respect to key parameters of MPB. (a) The cycle life; (b) the discharging efficiency; (c) sources of electricity for the life cycle of MPB.

First, we examine the GWP value of MPB when its cycle life changes. In Figure 9a, it is noted that extending the cycle life of LIB based MPB from 300 to 600 times would increase the value of GWP by $56 \%$. Similarly, as the cycle life of LIPB is halved or doubled, the initial value of GWP would be changed between $-54 \%$ and $38 \%$. It shows that cycle life plays a considerable role in the environmental performance of MPB life cycle, the smaller the cycle life, the lower the electricity loss in the use phase and hence the smaller the proportion of the use phase impacts in its life cycle. Further, it also be noted that higher utilization of cycle life is very useful for bringing down the life cycle impacts of both MPBs.

To the best of our knowledge, the relationship between MPB behaving pattern and battery aging has not been fully explored [45]. Figure $9 \mathrm{~b}$ shows that the GWP value decreases with the increasing discharging efficiency, and the reduction rate of LIPB is slightly greater than that of LIB. It means that the impact of LIPB is more sensitive to the changes in the discharging efficiency. Relative to the initial discharging efficiency in the use phase of LIB based MPB, a $10 \%$ reduction yields a $26 \%$ increase in the GWP value of MPB's life cycle, and a 10\% increase can yield a $20 \%$ reduction reversely. Hence, when the discharging efficiency drops to a certain value, the energy consumption during the use phase is 
much larger than that in the initial state, and the overall environmental impacts of MPB's life cycle could be greater than those of a new one. In this case, it is not always beneficial to maximize the cycle life of MPB from an environmental viewpoint, and an optimal retirement point should be determined to achieve the minimization of the life cycle environmental impacts.

A sensitivity analysis with respect to the electricity consumption during the use phase of MPB is performed in Figure 9c. Compared with the current electricity mix, a 17\% increase in the GWP value occurs when electricity is generated based on coal. In the third scenario where the electricity is based on natural gas, a $23 \%$ reduction in the GWP value is achieved. In the last two scenarios, the electricity is generated based on nuclear and hydro, leading to a noticeable $56 \%$ decrement when compared with the current electricity mix. While these two cleaner energy sources could achieve environmental and climatic benefits, they are also economically competitive to high carbon-intensive energy sources [46].

In sum, according to the results of sensitivity analysis, the overall environmental performance of two types of MPB can be further approved by improving the initial charging efficiency, replacing a new MPB after a certain number of cycle life and choosing low carbon-intensive electricity sources like natural gas and hydro as well.

\subsection{Resource Depletion}

The increasing demand for MPBs leads to a significant amount of metal depletion, and this study investigates the consumption of lithium, cobalt, and copper, which are frequently studied in the battery literature [47]. Based on the sales data acquired from Gu et al. [1], Figure 10 presents the metal depletion, including cobalt, lithium, and copper, in the Chinese MPB industry between the years 2010 and 2020. From the year 2010 to 2015, there is nearly a twelve-fold increase in the metal depletion, and the depletion of copper is much larger than the other two metals, with a significant increase from 330 to 3946 tons by the end of 2015. Since 2016, the metal demand in the Chinese MPB industry is supposed to continue increasing, while the growth tends to flatten as the market gradually becomes saturated. For example, the demand of cobalt will reach 2520 tons with a growth rate of $2.6 \%$ in the year 2020, and this demand will be twice as large as in the year 2015. The prospects and benefits from the recovery of the three metals above are discussed as follows.

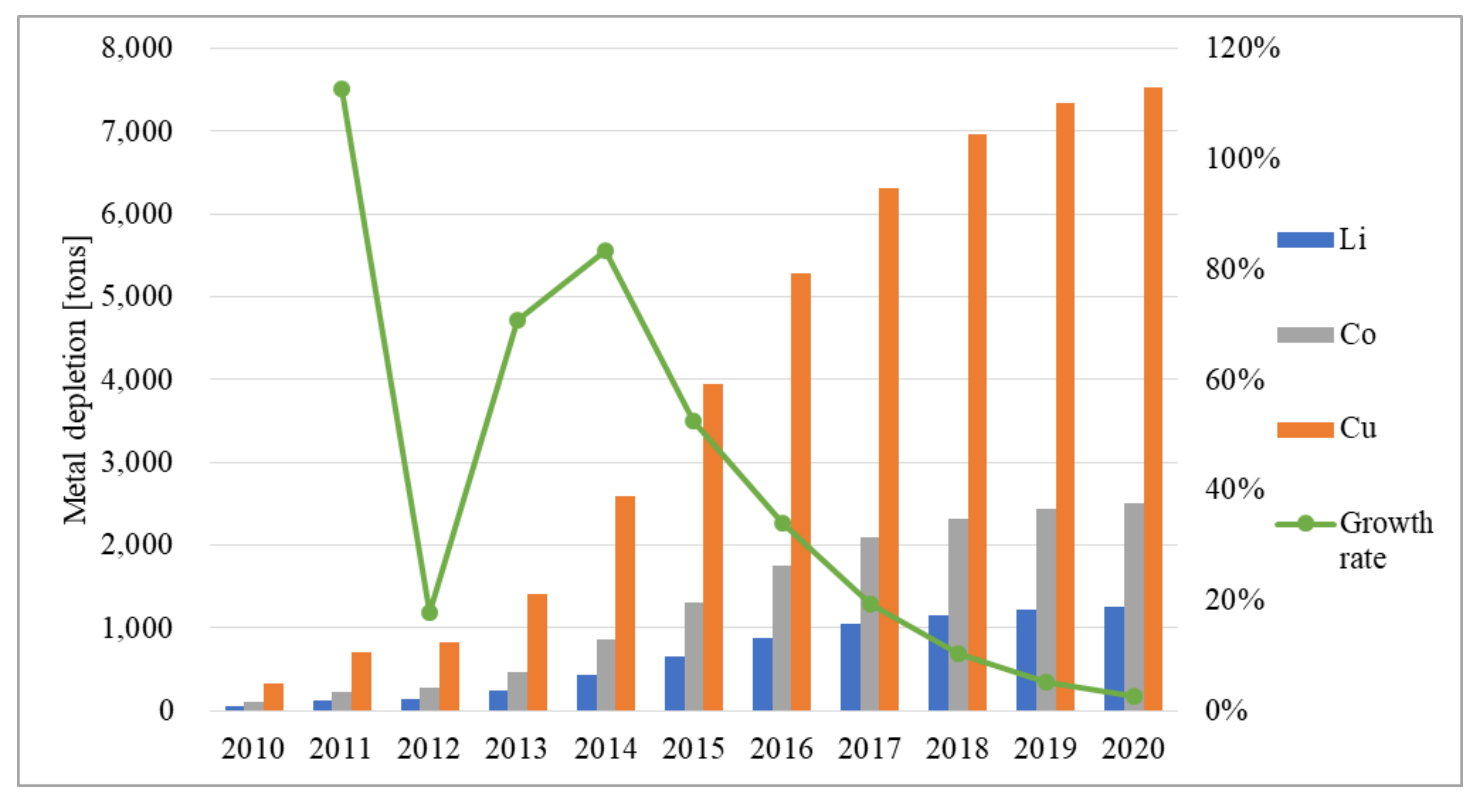

Figure 10. The evaluation of metal demand of MPB industry in 2010-2020, in tons.

Lithium: As shown in Figure 10, the lithium content in the MPB is much lower when compared with the content of cobalt and copper, and this can lead to an inefficient recovery of lithium [48]. Besides, 
due to the low present price, lithium is unlikely to be recycled in the current recycling system [1]. Currently, it is believed that there is no danger of running out of lithium resource in this century, but a high potential of supply shortage could be identified $[49,50]$. Thus, a dynamic monitoring of continued use of lithium should be considered, and improvement of the process efficiency is essential to shave this potential of lithium supply disruption.

Cobalt: With rapid proliferation of LIBs, China's cobalt deposits are strained, and the availability and carrying capacity of cobalt resources have received much attention [51]. China has started to pose rigorous regulations on promoting the recycling of spent LIBs and cobalt products, with the objective of elevating the resource efficiency and enhancing the carrying capacity [52]. Zeng and Li suggested that $90 \%$ recycling rate of cobalt should be achieved to meet the ever-increasing demand [53]. In this study, a hydrometallurgical procedure that is supposed to achieve $90 \%$ cobalt recycling rate is used in modeling, but the procedure has not yet been widely practiced. The government is supposed to support the popularization of advanced recycling technologies to ensure the long-term stability in the metal supply.

Copper: There is no complete close-loop of metal resource for the current MPB industry; the production of batteries requires only pristine materials, as secondary copper is placed in other applications [36]. Here we calculate the environmental savings associated with replacing the pristine copper with the secondary copper. The result shows that using all-recycled copper in the MPB production can largely reduce the total MDP value by $59 \%$, and an averaging $24 \%$ reduction of all other categorized impacts. It is of great benefits to promote recycling of resources in MPB, and more advanced recycling technologies are required to improve the quality of recycled materials, thus realizing the material circulation in MPB industry.

\section{Discussion}

To address the knowledge gaps in understanding the environmental performance of MBP, this study compiles a complete LCI of MPB. The LCA results show that the production of NMC in the cathode and copper in the anode brings great environmental burdens. Thus, from the environmental point of view, battery production has a large room for improvement; reducing energy consumption, optimizing material efficiency of cathode materials and aluminum shell in the battery production process has significant effect on reducing the environmental impact of MPB. In addition, owning to its high energy density and long cycle life [54], NMC remains as the most commonly-used cathode material before 2025 [55]. Therefore, measures like developing new generations of batteries and improving manufacturing processes can be proposed to alleviate the material's environmental impacts. Amongst the candidates, developing new generations of batteries is a research hotspot. For example, lithium sulfide (LiS) is considered as a promising candidate [56], as it is composed of raw materials with adequate supplement and environmental benignity. However, due to technical challenges like unstable electrochemistry and deteriorated performance of both electrodes, it still has a long way to go in its commercial application.

This study shows that LIPB based MPB exhibit a significantly better environmental performance than LIB and its MPB. Combined with multiple advantages such as high energy density, safety, and design flexibility [6], extending the market share of LIPB based MPB seems to be an environmentally friendly practice, yet its price is still higher than that of LIB, hindering its applicability. The results of the sensitivity analysis show that it is more environmentally friendly to expand the cycle life of both types of batteries. However, due to the degradation of capacity and efficiency during each cycle [57], it might not always be wise to increase the quantity of the cycle life of these batteries. Hence, attention should be paid on investigating the degradation behaviors of these batteries and developing battery management strategies, with the objective of finding an optimal retirement point to minimize the life cycle costs and environmental impacts of MPB. Moreover, with the appearance and wide spread of sharing MPBs lately, this result can be used as a reference for the market management and recycling strategy of sharing MPB from the environmental perspective. 
From the view point of resource management, the metal demand including cobalt and lithium in the Chinese MPB industry is supposed to continue increasing, although the growth tends to flatten. Efficient recycling of MPB is proved to effectively ease the burden of resource depletion, achieving a $42 \%$ reduction of MDP. Consequently, the MPB recycling should be incorporated into the existing WEEE recycling system. However, battery recycling has not been widely adopted and practiced, as there are less than $10 \%$ of LIBs used in CEs are recycled in the extant recycling system [1]. To promote the recycling rate of $\mathrm{MPB}$, a series of options should be considered. First, it is of great importance to propose a standardized MPB disposal procedure, in which the determination of retirement point and disposal/recycling processes should be included. Secondly, with the implementation of EPR of China published in January 2017 [58], stakeholders are supposed to strengthen the life cycle management of their own products. A clear delineation of the responsibilities of each stakeholder in every recycling phases is highly desirable. Moreover, administrators should pay more attention to supporting licensed disposers in adopting advanced processes.

\section{Conclusions}

This study applies an LCA method to assess the life cycle environmental impacts of the typical MPBs; the differences in the environmental performance of MPB based on two types of batteries are assessed and compared. Our results suggest that the MPB production dominates most categorized environmental impacts, attributed to the use of cathode material NMC and anode material copper in the battery. The electricity consumption during the use phase greatly affects climate change and fossil depletion. In general, LIPB based MPB is environmentally friendlier than LIB based MPB. Due to the capacity degradation, improving the initial charging efficiency and replacing a new MPB after a certain number of cycle life might effectively alleviate the environmental impact. Another potential route for environmental improvement is to use less carbon-intensive energy sources such as nuclear and hydro. Further, an efficient recycling process is needed to reduce the environmental impact of MPB, as well as ease the burden of resource depletion; and recycling criteria for different metals like lithium and cobalt should be differentiated. Implications of the mitigating opportunities of MPB industry are given in three aspects: (1) seeking environmentally-friendlier battery chemistries; (2) managing to reduce the manufacturing cost of LIPB based MPB and promoting the use of LIPB based MPB; (3) developing an effective MPB recycling industry and legal system.

The study could be used by stakeholders to gauge current environmental performance of MPB. It could also serve as a tool to facilitate managerial decisions and even direct measures to improve the environmental performance of MPB industry. The future research can be extended in the following directions: (1) to improve accuracy and inclusiveness of the LCI data, (2) to model the degradation behaviors of MPB to determine optimal retirement point and provide guidance for the management and recycling strategy of sharing MPB, (3) to incorporate MPB recycling into the existing WEEE recycling system and seek for proper end-of-life management for MPB that maximizes the environmental benefits.

Author Contributions: Conceptualization, F.G. and J.Y.; methodology, J.Y. and J.G.; validation, B.C., and J.G.; formal analysis, J.Y.; data curation, J.Y.; writing—original draft preparation, J.Y.; writing—review and editing, F.G. and J.Y.; visualization, J.Y.; project administration, F.G.

Funding: This study is financially supported by National Natural Science Foundation Project (nos. 71832013 and 71901194), Natural Science Foundation of Zhejiang Province (no. LY19G010009), and Fundamental Research Funds for the Central Universities (no. 2018QNA4007).

Conflicts of Interest: The author declares no conflict of interest. 


\section{Appendix A}

Table A1. Parameters of fifty best-selling MPB models on JD.com.

\begin{tabular}{|c|c|c|c|c|c|c|c|c|c|c|c|}
\hline Rank & Brand & Model & Capacity & Mass & Size $(\mathrm{mm})$ & Battery & $\begin{array}{c}\text { Packaging } \\
\text { Material }\end{array}$ & $\begin{array}{l}\text { Theoretical } \\
\text { Cycle Life }\end{array}$ & $\begin{array}{l}\text { Theoretical } \\
\text { Efficiency }\end{array}$ & $\begin{array}{l}\text { Additional } \\
\text { Component }\end{array}$ & $\begin{array}{c}\text { Price } \\
\text { (RMB) }\end{array}$ \\
\hline 1 & Xiaomi & PLM06ZM & $20,000 \mathrm{mAh} / 74 \mathrm{WH}$ & $358 \mathrm{~g}$ & L149.5 * W69.6 * H24 & LIPB & Plastic & & $\sim 93 \%$ & - & 129 \\
\hline 2 & ROMOSS & sense 6 & $20,000 \mathrm{mAh} / 74 \mathrm{WH}$ & $445 \mathrm{~g}$ & $\mathrm{~L} 160 * \mathrm{~W} 80 * \mathrm{H} 22.6$ & LIPB & Plastic & $>300$ & $\sim 85 \%$ & - & 99 \\
\hline 3 & Xiaomi & 2 & $10,000 \mathrm{mAh} / 37 \mathrm{WH}$ & $260 \mathrm{~g}$ & $\mathrm{~L} 147 * \mathrm{~W} 71 * \mathrm{H} 14$ & LIPB & Aluminum alloy & - & $\sim 90 \%$ & - & 79 \\
\hline 4 & ROMOSS & sense $6 \mathrm{LCD}$ & $20,000 \mathrm{mAh} / 74 \mathrm{WH}$ & $445 \mathrm{~g}$ & $\mathrm{~L} 160$ * W80 * H22.6 & LIPB & Plastic & $>300$ & $\sim 85 \%$ & LCD & 99 \\
\hline 5 & HUAWEI & AP20Q & $20,000 \mathrm{mAh} / 74 \mathrm{WH}$ & $374 \mathrm{~g}$ & $\mathrm{~L} 150 * \mathrm{~W} 79 * \mathrm{H} 22.5$ & LIB & Plastic & - & $\sim 85 \%$ & - & 299 \\
\hline 6 & ROMOSS & sense 9 & $25,000 \mathrm{mAh} / 92.5 \mathrm{WH}$ & $585 \mathrm{~g}$ & $\mathrm{~L} 210 * \mathrm{~W} 80 * \mathrm{H} 22.6$ & LIPB & Plastic & $>300$ & $\sim 85 \%$ & - & 119 \\
\hline 7 & ROMOSS & $\mathrm{HO} 20$ & $20,000 \mathrm{mAh} / 74 \mathrm{WH}$ & $450 \mathrm{~g}$ & L168 * W82* H22.5 & LIPB & Plastic & - & - & LED & 89 \\
\hline 8 & PHILIPS & DLP2103 & $10,000 \mathrm{mAh} 3.8 \mathrm{~V} / 38 \mathrm{WH}$ & $201 \mathrm{~g}$ & L148* W78* H10.9 & LIPB & Plastic & $>500$ & - & - & 149 \\
\hline 9 & Aigo & E10000 & $10,000 \mathrm{mAh} / 37 \mathrm{WH}$ & $210 \mathrm{~g}$ & L115. * * W66. $2 * \mathrm{H} 22$ & LIPB & Plastic & sou & 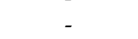 & LED & 79 \\
\hline 10 & ROMOSS & sense 4 & $10,400 \mathrm{mAh} 3.7 \mathrm{~V} / 38.5 \mathrm{WH}$ & $296 \mathrm{~g}$ & $\mathrm{~L} 138 * \mathrm{~W} 62 * \mathrm{H} 22$ & LIB & Plastic & $>300$ & $\sim 85 \%$ & - & 59 \\
\hline 11 & Xiaomi & & $10,000 \mathrm{mAh} / 37 \mathrm{WH}$ & $260 \mathrm{~g}$ & L128.5 * W75 * H12.5 & LIPB & Aluminum alloy & - & $\sim 93 \%$ & - & 149 \\
\hline 12 & PISEN & TS-D199 & $20,000 \mathrm{mAh} / 74 \mathrm{WH}$ & $475 \mathrm{~g}$ & $\mathrm{~L} 161 * \mathrm{~W} 83 * \mathrm{H} 23$ & LIB & Plastic & - & $\sim 90 \%$ & LCD & 129 \\
\hline 13 & Aigo & E20000 & $20,000 \mathrm{mAh} / 74 \mathrm{WH}$ & $396 \mathrm{~g}$ & $\mathrm{~L} 162.3 * \mathrm{~W} 76.3 * \mathrm{H} 21.7$ & LIPB & Plastic & - & - & LED & 118 \\
\hline 14 & ROMOSS & sense $6 \mathrm{P}$ & $20,000 \mathrm{mAh} / 74 \mathrm{WH}$ & $445 \mathrm{~g}$ & $\mathrm{~L} 160 * \mathrm{~W} 80^{*} \mathrm{H} 22.6$ & LIPB & Plastic & $>300$ & $\sim 85 \%$ & LED & 99 \\
\hline 15 & Aigo & W200 & $20,000 \mathrm{mAh} / 74 \mathrm{WH}$ & $465 \mathrm{~g}$ & $\mathrm{~L} 165.2 * \mathrm{~W} 78 * \mathrm{H} 23$ & LIB & Plastic & - & - & LED & 99 \\
\hline 16 & Xiaomi & . & $5000 \mathrm{mAh} / 18.5 \mathrm{WH}$ & $190 \mathrm{~g}$ & L125 * W69 * H9.9 & LIPB & Aluminum alloy & - & - & - & 59 \\
\hline 17 & TAIHUO & TW4 & $5000 \mathrm{mAh} / 18.5 \mathrm{WH}$ & $109 \mathrm{~g}$ & $\mathrm{H} 8$ & LIPB & Plastic & - & - & - & 138 \\
\hline 18 & MORUI & ML20 & $20,000 \mathrm{mAh} / 74 \mathrm{WH}$ & $445 \mathrm{~g}$ & $\mathrm{~L} 157 *$ W71 * H24 & LIB & Plastic & $>300$ & $\sim 90 \%$ & LED & 79 \\
\hline 19 & ZMI & MF885 & $10,000 \mathrm{mAh} / 37 \mathrm{WH}$ & $257 \mathrm{~g}$ & $\mathrm{~L} 111.5 * \mathrm{~W} 70 * \mathrm{H} 22$ & LIB & Aluminum alloy & 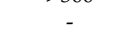 & - & Portable router & 399 \\
\hline 20 & HUAWEI & AP09S & $5000 \mathrm{mAh} / 18.5 \mathrm{WH}$ & $252 \mathrm{~g}$ & $\mathrm{~L} 138 * \mathrm{~W} 71 * \mathrm{H} 16$ & LIPB & Aluminum alloy & - & $\sim 91 \%$ & & 229 \\
\hline 21 & PHILIPS & DLP1130V & $10,000 \mathrm{mAh} / 38 \mathrm{WH}$ & $210 \mathrm{~g}$ & $\mathrm{~L} 160 * \mathrm{~W} 80 * \mathrm{H} 11$ & LIPB & Plastic & - & - & Cable & 249 \\
\hline 22 & HUAWEI & AP09Q & $10,000 \mathrm{mAh} / 37 \mathrm{WH}$ & $252 \mathrm{~g}$ & L138* W71 * H15.9 & LIPB & Aluminum alloy & - & $\sim 89 \%$ & - & 169 \\
\hline 23 & DIVI & & $5000 \mathrm{mAh} / 18.5 \mathrm{WH}$ & $118 \mathrm{~g}$ & L141 * W70 * H15 & LIPB & $\begin{array}{l}\text { Plastic } \\
\text { P }\end{array}$ & - & - & - & 109 \\
\hline 24 & PHILIPS & DLP2109 & $10,000 \mathrm{mAh} / 37 \mathrm{WH}$ & $220 \mathrm{~g}$ & L149* W78 * H12.5 & LIPB & Aluminum alloy & - & - & LCD & 139 \\
\hline 26 & $\mathrm{ZMI}$ & QB815 & $15,600 \mathrm{mAh} 3.6 \mathrm{~V} / 56.16 \mathrm{WH}$ & $393 \mathrm{~g}$ & L160.4 * W81.4 * H21 & LIB & Aluminum alloy & - & $\sim 90 \%$ & - & 239 \\
\hline 27 & TECLAST & $\mathrm{A} 10-\mathrm{R}$ & $10,000 \mathrm{mAh} / 37 \mathrm{WH}$ & $179 \mathrm{~g}$ & $\mathrm{~L} 88 * \mathrm{~W} 62 * \mathrm{H} 23$ & LIB & Plastic & - & $\sim 93 \%$ & - & 129 \\
\hline 28 & KNK & A-50000 & $20,000 \mathrm{mAh} / 74 \mathrm{WH}$ & - & $\mathrm{L} 170 * \mathrm{~W} 106 * \mathrm{H} 15$ & - & Plastic & - & $\sim 95 \%$ & LED & 79 \\
\hline 29 & Besiter & BST-0137DT & $10,000 \mathrm{mAh} / 37 \mathrm{WH}$ & $244 \mathrm{~g}$ & $\mathrm{~L} 100 * \mathrm{~W} 78 * \mathrm{H} 23$ & LIB & Plastic & - & $\sim 85 \%$ & - & 69.9 \\
\hline 29 & Besiter & BST-K6X & $20,000 \mathrm{mAh} / 74 \mathrm{WH}$ & $465 \mathrm{~g}$ & $\mathrm{~L} 165 * \mathrm{~W} 80 * \mathrm{H} 22$ & LIPB & Plastic & $=$ & $\sim 60 \%$ & LED & 89 \\
\hline 30 & PHILIPS & DLP2119 & $20,000 \mathrm{mAh} / 74 \mathrm{WH}$ & $425 \mathrm{~g}$ & L161.3 * W82. * $^{*} \mathrm{H} 24.5$ & LIPB & Aluminum alloy & - & - & LED & 239 \\
\hline 31 & Besiter & G-5 & $5000 \mathrm{mAh} / 18.5 \mathrm{WH}$ & $100 \mathrm{~g}$ & $\mathrm{~L} 140 * \mathrm{~W} 70 * \mathrm{H} 5.7$ & LIPB & Plastic & - & - & - & 199 \\
\hline 32 & ROMOSS & PB10 & $10,000 \mathrm{mAh} / 37 \mathrm{WH}$ & $204 \mathrm{~g}$ & L142* W65* H14.8 & LIPB & Plastic & $>600$ & $\sim 85 \%$ & - & 69 \\
\hline 33 & ANKER & A1621 & $5000 \mathrm{mAh} / 18.5 \mathrm{WH}$ & $189 \mathrm{~g}$ & $\mathrm{~L} 72 * \mathrm{~W} 70 * \mathrm{H} 31$ & LIB & Plastic & & - & Charger & 148 \\
\hline 34 & HUAWEI & AP08Q & $10,000 \mathrm{mAh} / 37 \mathrm{WH}$ & $215 \mathrm{~g}$ & $\mathrm{~L} 139 * \mathrm{~W} 73.7 * \mathrm{H} 15.5$ & LIPB & Plastic & - & - & - & 139 \\
\hline 35 & PADO & $\mathrm{K} 20$ & $21,200 \mathrm{mAh} / 78.44 \mathrm{WH}$ & $440 \mathrm{~g}$ & L153*W77* H19 & LIB & Plastic & $>3000$ & - & - & 69 \\
\hline 36 & TECLAST & T100CE & $10,000 \mathrm{mAh} / 37 \mathrm{WH}$ & $278.9 \mathrm{~g}$ & L140.1 * $64.05 * \mathrm{H} 22$ & LIB & Plastic & - & - & - & 49 \\
\hline 37 & $\mathrm{~F} \& \mathrm{O}$ & F4 & $7000 \mathrm{mAh} / 25.9 \mathrm{WH}$ & $160 \mathrm{~g}$ & $\mathrm{~L} 142 * \mathrm{~W} 72 * \mathrm{H} 16$ & LIPB & Plastic & - & - & - & 148 \\
\hline 38 & YICF & Y50000 & $20,000 \mathrm{mAh} / 74 \mathrm{WH}$ & $205 \mathrm{~g}$ & $\mathrm{~L} 153 * \mathrm{~W} 75 * \mathrm{H} 10$ & LIPB & Aluminum alloy & - & $\sim 93 \%$ & Solar panel & 69.9 \\
\hline 39 & ROMOSS & HO10C & $10,000 \mathrm{mAh} / 37 \mathrm{WH}$ & $220 \mathrm{~g}$ & L145* W73.5*H15 & LIPB & Plastic & - & - & LED & 79 \\
\hline 41 & KNK & 50000 & $20,000 \mathrm{mAh} / 74 \mathrm{WH}$ & $280 \mathrm{~g}$ & $\mathrm{~L} 160 * \mathrm{~W} 78 * \mathrm{H} 10$ & LIPB & Aluminum alloy & - & - & - & 69 \\
\hline 42 & PISEN & TS-D189 & $10,000 \mathrm{mAh} / 37 \mathrm{WH}$ & $301 \mathrm{~g}$ & L130.5 * W61 * H31.5 & LIB & Plastic & - & - & Charger & 78.9 \\
\hline 43 & PHILIPS & DLP1201V & $20,000 \mathrm{mAh} 3.8 \mathrm{~V} / 76 \mathrm{WH}$ & $378 \mathrm{~g}$ & $\mathrm{~L} 160 * \mathrm{~W} 80$ * H19.5 & LIPB & Plastic & - & - & Cable & 369 \\
\hline 44 & ZMI & APB01 & $6500 \mathrm{mAh} 3.63 \mathrm{~V} / 23.6 \mathrm{WH}$ & $199 \mathrm{~g}$ & $\mathrm{~L} 72 * \mathrm{~W} 70.5 * \mathrm{H} 31.6$ & LIB & Plastic & - & - & Charger & 129 \\
\hline 46 & KELIFANG & $50000 \mathrm{M}$ & $20,000 \mathrm{mAh} / 74 \mathrm{WH}$ & $400 \mathrm{~g}$ & $\mathrm{~L} 160 * \mathrm{~W} 80 * \mathrm{H} 20$ & LIB & Aluminum alloy & $>800$ & $\sim 93 \%$ & LED & 98 \\
\hline 47 & SOLOVE & A8 & $20,000 \mathrm{mAh} 3.8 \mathrm{~V} / 76 \mathrm{WH}$ & $528 \mathrm{~g}$ & L166 *W116*H15 & LIPB & Aluminum alloy & 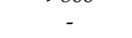 & $\sim 93 \%$ & - & 139 \\
\hline 50 & Aigo & OL10400 & $10,400 \mathrm{mAh} 3.7 \mathrm{~V} / 38.5 \mathrm{WH}$ & $240 \mathrm{~g}$ & $\mathrm{~L} 90 * \mathrm{~W} 90 * \mathrm{H} 23$ & LIB & Plastic & - & - & - & 64.9 \\
\hline
\end{tabular}


Table A2. Data and assumptions for the life cycle of MPB (an extension of Table 2).

\begin{tabular}{|c|c|c|c|c|c|c|}
\hline \multirow{2}{*}{ Module } & \multirow{2}{*}{ Component } & \multirow{2}{*}{ Subcomponent } & \multirow{2}{*}{ Description of Data and Assumptions Used } & \multicolumn{2}{|c|}{ Mean Value } & \multirow{2}{*}{ Unit } \\
\hline & & & & LIB & LIPB & \\
\hline \multirow{9}{*}{ Battery cell } & \multirow{2}{*}{ Anode } & $\begin{array}{l}\text { Negative electrode } \\
\text { paste }\end{array}$ & $\begin{array}{l}\text { Datasets "graphite, RoW", "carbon black, RoW" and the binder "latex, RoW" are used, with the dataset "deionised water, } \\
\text { RoW" as the solvent. }\end{array}$ & 0.0030 & 0.0024 & $\mathrm{~g} / \mathrm{Wh}$ \\
\hline & & $\begin{array}{l}\text { Negative electrode } \\
\text { substance }\end{array}$ & Datasets "copper ingot, RoW" and "sheet rolling, copper, RoW" are used. & 0.0027 & 0.0006 & $\mathrm{~g} / \mathrm{Wh}$ \\
\hline & \multirow[t]{2}{*}{ Cathode } & $\begin{array}{l}\text { Positive electrode } \\
\text { paste }\end{array}$ & $\begin{array}{l}\text { The inventory of NMC production from } \mathrm{LiOH} \text { and } \mathrm{Ni}_{0.4} \mathrm{Co}_{0.2} \mathrm{Mn}_{0.4}(\mathrm{OH})_{2} \text { is based on protocol descriptions by } \\
\text { Majeau-Bettez et al. [24]. } \\
\text { Datasets "tetrafluoroethylene, RoW", " polyethylene, RoW" and "N-methyl-2-pyrrolidone, RoW" are used as the binder and } \\
\text { solvent respectively. Since no LCA data exists for PVDF, it is substituted with equal amounts of TFE and PE. }\end{array}$ & 0.0075 & 0.0029 & $\mathrm{~g} / \mathrm{Wh}$ \\
\hline & & $\begin{array}{l}\text { Positive electrode } \\
\text { substance }\end{array}$ & Datasets "aluminium ingot, $R o W^{\prime}$ " and "sheet rolling, aluminium, $R o W^{\prime}$ " are used. & 0.0012 & 0.0003 & $\mathrm{~g} / \mathrm{Wh}$ \\
\hline & \multirow[t]{2}{*}{ Electrolyte } & Solvent & 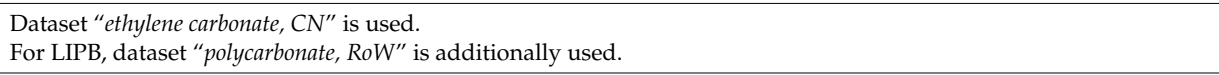 & \multirow[t]{2}{*}{0.0039} & \multirow[t]{2}{*}{0.0009} & \multirow[t]{2}{*}{$\mathrm{g} / \mathrm{Wh}$} \\
\hline & & Salt & Dataset "lithium hexafluorophosphate, $\mathrm{CN}^{\prime}$ is used. & & & \\
\hline & Separator & - & Dataset "separator, $R o W$ " is used. & 0.0011 & 0.0002 & $\mathrm{~g} / \mathrm{Wh}$ \\
\hline & Cell container & - & $\begin{array}{l}\text { Datasets "aluminium ingot, RoW" and "sheet rolling, aluminium, } R_{0} W^{\prime \prime} \text { are used. } \\
\text { For LIPB, since no LCA data exists for aluminum plastic foil, it is substituted with the combination of dataset "glass } \\
\text { fiber reinforced plastic, RoW", "aluminium ingot, RoW" and "polypropylene granulate, RoW". }\end{array}$ & 0.0065 & 0.0028 & $\mathrm{~g} / \mathrm{Wh}$ \\
\hline & Assembly & - & Dataset "electricity, $C N$ " is used, and the data is based on the estimation of Majeau-Bettez et al. [24]. & 0.0257 & 0.0101 & $\lg$ \\
\hline РСВ & - & - & $\begin{array}{l}\text { Datasets "integrated circuit production, GLO", "copper ingot, RoW" and "chromium steel 18/8, RoW" are used, for which the } \\
\text { future processing dataset "wire drawing, copper, RoW" and "sheet rolling, chromium steel, RoW" are also used. }\end{array}$ & 0.0011 & 0.0004 & $\mathrm{~g} / \mathrm{Wh}$ \\
\hline \multirow{3}{*}{ Packaging } & Shell & - & Datasets "aluminum alloy, RoW" and "hot rolling, steel, RoW" are used. & 0.0089 & 0.0051 & $\mathrm{~g} / \mathrm{Wh}$ \\
\hline & Tray & - & $\begin{array}{l}\text { Datasets "polypropylene granulate, RoW" and "extrusion and thermoforming, RoW" are used, and the tray is used to fix } \\
\text { the batteries. }\end{array}$ & 0.0013 & 0.0011 & $\mathrm{~g} / \mathrm{Wh}$ \\
\hline & Other & - & Dataset "chromium steel $18 / 8$, RoW" and "low density polyethylene, RoW" are used. & 0.0009 & 0.0003 & $\mathrm{~g} / \mathrm{Wh}$ \\
\hline Process & \multicolumn{3}{|r|}{ Description of Data and Assumptions Used } & & & \\
\hline Transportation & \multicolumn{3}{|c|}{$\begin{array}{l}\text { The transportation data for each component production is based on Majeau-Bettez et al. [24] and Notter et al. [23]; the datasets "transport, freight, lorry, RoW" and } \\
\text { "transport, freight train, diesel, CN" are used. }\end{array}$} & 1 & 1 & I \\
\hline Assembly & \multicolumn{3}{|l|}{ No available data. } & 1 & 1 & 1 \\
\hline Use & \multicolumn{3}{|c|}{$\begin{array}{l}\text { Based on the assumption of a complete charge and discharge every time, dataset "electricity, } \mathrm{CN}^{\prime} \text { " is used; and there is no other output during the use phase. } \\
\text { It is assumed that there are no maintenance activities in the use phase. }\end{array}$} & 6.8875 & 12.9071 & $\mathrm{kWh}$ \\
\hline \multirow{4}{*}{ Recycling } & Disassembly & \multicolumn{2}{|c|}{ This process is performed manually, assuming no energy consumption. } & 1 & 1 & 1 \\
\hline & Battery & \multicolumn{2}{|c|}{$\begin{array}{l}\text { The inventory of battery recycling is based on Hao et al. [27], in which an optimized hydrometallurgical process is adopted. Active anode } \\
\text { materials (NMC) and copper are recycled from this process. }\end{array}$} & 0.0257 & 0.0101 & $\mathrm{~g} / \mathrm{Wh}$ \\
\hline & РСВ & \multicolumn{2}{|c|}{$\begin{array}{l}\text { According to } \mathrm{Li} \text { and } \mathrm{Xu}[34] \text { and Ghosh et al. [28], PCBs are shredded mechanically into metal powder, and copper is extracted through the } \\
\text { hydrometallurgical route, with a recycling rate of } 95 \% \text {. }\end{array}$} & 0.0011 & 0.0004 & $\mathrm{~g} / \mathrm{Wh}$ \\
\hline & Packaging & \multicolumn{2}{|c|}{ Quantifying with the $75 \%$ reduction of environmental impact of aluminum alloy production. } & 0.0112 & 0.0066 & $\mathrm{~g} / \mathrm{Wh}$ \\
\hline
\end{tabular}




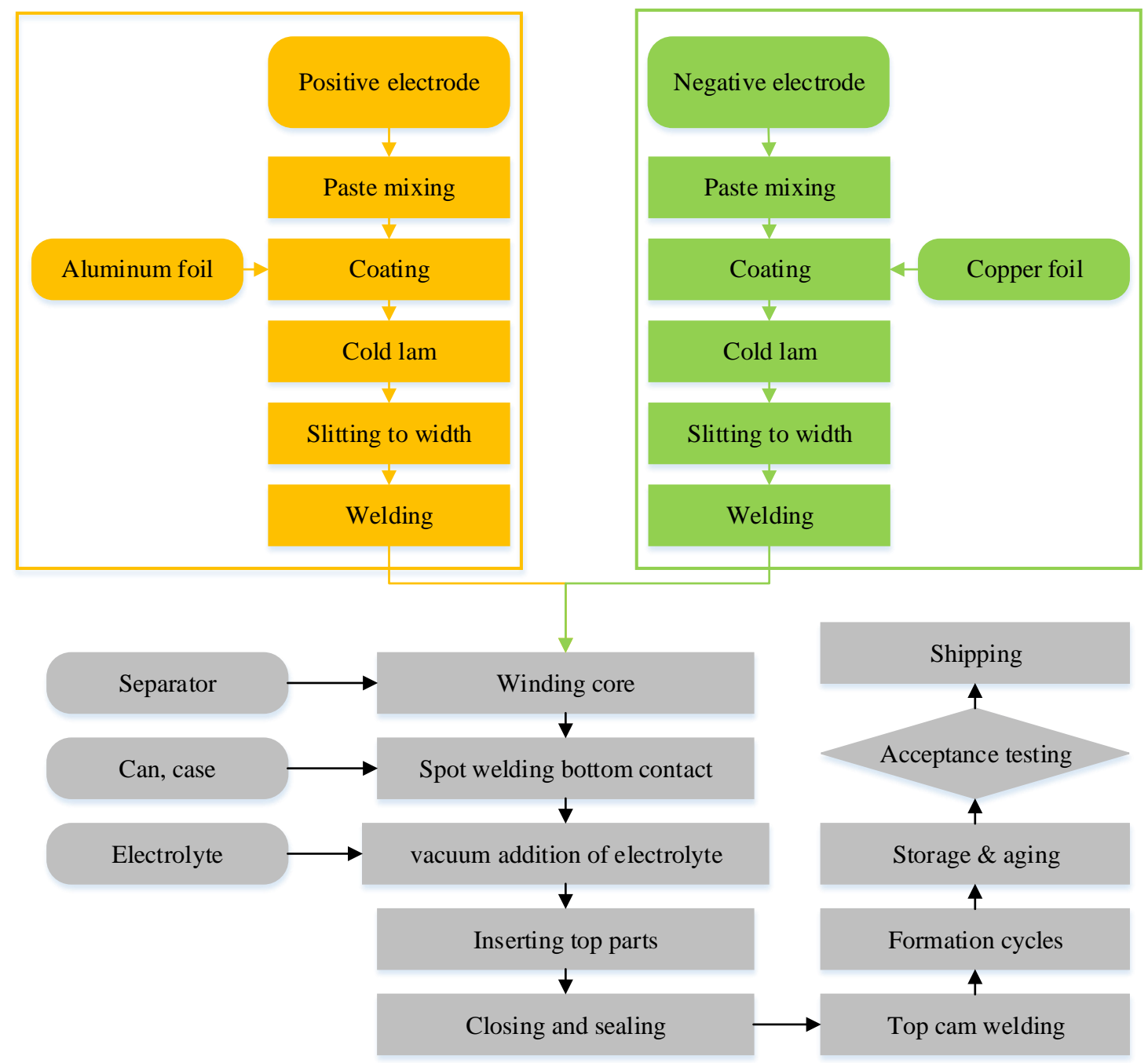

Figure A1. Schematic of battery assembly processes. The 18650-battery cell consists of five subcomponents: anode, cathode, separator, electrolyte, and cell container; typical processes used for production of small commercial 18650-battery are described here.

1. The cathode paste is made of $\mathrm{Li}\left(\mathrm{Ni}_{0.4} \mathrm{Co}_{0.2} \mathrm{Mn}_{0.4}\right) \mathrm{O}_{2}$, small amounts of carbon black, binder, and other additives. These materials are mixed in a chemical vessel and then pumped to the coating machine.

2. Coating machines spread the paste on both sides of the Aluminum foil, drying the foil and calendaring it to make the thickness more uniform and then slit to the desirable sizes.

3. The anode paste is made of synthetic graphite and s binders in a process similar to that used for the cathode paste and then spread on copper foil to produce the anodes.

4. The separator is a porous low-density polyethylene (LDPE) film, and the dried three-layer assembly is calendared, slit, and cylindrically for the 18650 container.

5. The layers are secured within a polyethylene pouch and tucked into a steel canister. The battery cell is filled with a premixed non-aqueous electrolyte solution of lithium hexafluorophosphate (LiPF6) in ethylene carbonate.

6. The cell casing is sealed and the copper end tab is attached, then the laminated cell is racked, and it undergoes activation by charge-discharge cycling. Inspection and testing follow completion of the formation step. 
Table A3. Numerical results of environmental assessment of MPB's life cycle.

\begin{tabular}{|c|c|c|c|c|c|c|}
\hline \multicolumn{2}{|c|}{ ReCiPe Midpoint (H) } & \multirow{3}{*}{$\begin{array}{c}\begin{array}{c}\text { Production } \\
\text { Phase }\end{array} \\
0.651422 \\
0.237839\end{array}$} & \multirow{3}{*}{$\begin{array}{c}\text { Use Phase } \\
0.517195 \\
0.416381\end{array}$} & \multirow{3}{*}{$\begin{array}{c}\begin{array}{c}\text { Recycling } \\
\text { Phase }\end{array} \\
-0.02111 \\
-0.01285\end{array}$} & \multirow{3}{*}{$\begin{array}{c}\begin{array}{c}\text { Absolute } \\
\text { Value }\end{array} \\
1.189727 \\
0.667067\end{array}$} & \multirow{3}{*}{$\begin{array}{c}\text { Sum } \\
1.147508 \\
0.641373\end{array}$} \\
\hline & LIB & & & & & \\
\hline GWP & LIPB & & & & & \\
\hline \multirow{2}{*}{ FDP } & LIB & 0.161779 & 0.123802 & 0.00223 & 0.287812 & 0.287812 \\
\hline & LIPB & 0.05937 & 0.09967 & -0.00028 & 0.159324 & 0.158756 \\
\hline \multirow{2}{*}{ FETP } & LIB & 0.051562 & $3.31 \times 10^{-5}$ & -0.02186 & 0.073458 & 0.029732 \\
\hline & LIPB & 0.017274 & $2.66 \times 10^{-5}$ & -0.00908 & 0.026381 & 0.008222 \\
\hline \multirow{2}{*}{ FEP } & LIB & 0.001302 & $1.19 \times 10^{-7}$ & -0.00035 & 0.001653 & 0.000951 \\
\hline & LIPB & 0.000422 & $9.59 \times 10^{-8}$ & -0.00014 & 0.000564 & 0.000279 \\
\hline \multirow{2}{*}{ HTP } & LIB & 2.622341 & 0.090894 & -1.16186 & 3.875093 & 1.551376 \\
\hline & LIPB & 0.812216 & 0.073177 & -0.46071 & 1.346106 & 0.424678 \\
\hline \multirow{2}{*}{ METP } & LIB & 0.052201 & 0.000622 & -0.02376 & 0.076578 & 0.029068 \\
\hline & LIPB & 0.017102 & 0.000501 & -0.00976 & 0.027362 & 0.007842 \\
\hline \multirow{2}{*}{ MEP } & LIB & 0.000665 & $4.88 \times 10^{-5}$ & -0.00012 & 0.000833 & 0.000596 \\
\hline & LIPB & 0.000222 & $3.93 \times 10^{-5}$ & $-5.4 \times 10^{-5}$ & 0.000315 & 0.000207 \\
\hline \multirow{2}{*}{ MDP } & LIB & 0.547148 & 0.002465 & -0.39378 & 0.943393 & 0.155834 \\
\hline & LIPB & 0.190054 & 0.001984 & -0.15718 & 0.349224 & 0.034854 \\
\hline \multirow{2}{*}{ ODP } & LIB & $2.85 \times 10^{-6}$ & $1.62 \times 10^{-13}$ & $9.15 \times 10^{-9}$ & $2.86 \times 10^{-6}$ & $2.86 \times 10^{-6}$ \\
\hline & LIPB & $1.11 \times 10^{-6}$ & $1.31 \times 10^{-13}$ & $3.19 \times 10^{-9}$ & $1.11 \times 10^{-6}$ & $1.11 \times 10^{-6}$ \\
\hline \multirow{2}{*}{ PMPF } & LIB & 0.002742 & 0.000823 & -0.00134 & 0.004901 & 0.002229 \\
\hline & LIPB & 0.000932 & 0.000663 & -0.00054 & 0.002135 & 0.001056 \\
\hline \multirow{2}{*}{ POFP } & LIB & 0.002561 & 0.00129 & -0.0008 & 0.004647 & 0.003055 \\
\hline & LIPB & 0.000895 & 0.001038 & -0.00033 & 0.002265 & 0.001601 \\
\hline \multirow{2}{*}{ TAP } & LIB & 0.00886 & 0.001968 & -0.00574 & 0.016572 & 0.005083 \\
\hline & LIPB & 0.003066 & 0.001584 & -0.00229 & 0.006936 & 0.002365 \\
\hline \multirow{2}{*}{ TETP } & LIB & 0.000247 & $4.23 \times 10^{-5}$ & $-9.6 \times 10^{-5}$ & 0.000386 & 0.000193 \\
\hline & LIPB & $6.62 \times 10^{-5}$ & $3.4 \times 10^{-5}$ & $-4 \times 10^{-5}$ & 0.000141 & $5.99 \times 10^{-5}$ \\
\hline
\end{tabular}


Table A4. Numerical results of environmental assessment of MPB's production phase.

\begin{tabular}{|c|c|c|c|c|c|c|c|c|c|c|}
\hline \multicolumn{2}{|c|}{ ReCiPe Midpoint (H) } & \multirow{3}{*}{$\begin{array}{c}\text { Separator } \\
0.0088648 \\
0.004294915\end{array}$} & \multirow{3}{*}{$\begin{array}{c}\text { Cell Container } \\
0.035868947 \\
0.054078619\end{array}$} & \multirow{3}{*}{$\begin{array}{l}\text { Electrolyte } \\
0.158129365 \\
0.068369593\end{array}$} & \multirow{3}{*}{$\begin{array}{l}\text { Cathode } \\
0.254619 \\
0.270361\end{array}$} & \multirow{3}{*}{$\begin{array}{c}\text { Anode } \\
0.030754 \\
0.030771\end{array}$} & \multirow{3}{*}{$\begin{array}{c}\text { РСВ } \\
0.131772 \\
0.134495\end{array}$} & \multirow{3}{*}{$\begin{array}{c}\text { Packaging } \\
0.0540467 \\
0.0870993\end{array}$} & \multirow{3}{*}{$\begin{array}{c}\text { Battery Manufacturing } \\
0.32594563 \\
0.3505309\end{array}$} & \multirow{3}{*}{$\begin{array}{c}\text { Sum } \\
1 \\
1\end{array}$} \\
\hline & LIB & & & & & & & & & \\
\hline GWP & LIPB & & & & & & & & & \\
\hline \multirow{2}{*}{ FDP } & LIB & 0.014277904 & 0.037338646 & 0.20725733 & 0.141333 & 0.036845 & 0.143004 & 0.0682645 & 0.35168003 & 1 \\
\hline & LIPB & 0.006882164 & 0.081450791 & 0.090275585 & 0.147929 & 0.042509 & 0.145213 & 0.1094499 & 0.3762902 & 1 \\
\hline \multirow{2}{*}{ FETP } & LIB & 0.005108167 & 0.043439213 & 0.032911642 & 0.146874 & 0.262138 & 0.444067 & 0.0621099 & 0.00335166 & 1 \\
\hline & LIPB & 0.002697085 & 0.024652611 & 0.014728686 & 0.167993 & 0.183016 & 0.493941 & 0.1090812 & 0.00389077 & 1 \\
\hline \multirow{2}{*}{ FEP } & LIB & 0.001528506 & 0.016208797 & 0.043108548 & 0.077471 & 0.308621 & 0.52995 & 0.022303 & 0.00080899 & 1 \\
\hline & LIPB & 0.00083514 & 0.010587316 & 0.019861024 & 0.092295 & 0.224939 & 0.609991 & 0.0405336 & 0.00095744 & 1 \\
\hline \multirow{2}{*}{ HTP } & LIB & 0.000889172 & 0.01292937 & 0.056061804 & 0.064737 & 0.377956 & 0.456728 & 0.0180035 & 0.01269563 & 1 \\
\hline & LIPB & 0.000507819 & 0.008037145 & 0.026782496 & 0.080673 & 0.284204 & 0.549513 & 0.0342011 & 0.01608198 & 1 \\
\hline \multirow{2}{*}{ METP } & LIB & 0.004336379 & 0.038487043 & 0.041410277 & 0.141137 & 0.297171 & 0.416851 & 0.0551848 & 0.0054227 & 1 \\
\hline & LIPB & 0.002341391 & 0.022025921 & 0.018784517 & 0.165371 & 0.211742 & 0.47416 & 0.099112 & 0.00646316 & 1 \\
\hline \multirow{2}{*}{ MEP } & LIB & 0.007122754 & 0.047154884 & 0.217901644 & 0.219705 & 0.134342 & 0.267936 & 0.0675075 & 0.03833047 & 1 \\
\hline & LIPB & 0.003778112 & 0.073883244 & 0.099341469 & 0.254002 & 0.105507 & 0.299402 & 0.1191073 & 0.04497936 & 1 \\
\hline \multirow[b]{2}{*}{ MDP } & LIB & 0.000481439 & 0.022158053 & 0.017579123 & 0.441568 & 0.239912 & 0.234877 & 0.0413327 & 0.00209142 & 1 \\
\hline & LIPB & 0.000245174 & 0.011442203 & 0.007557937 & 0.496168 & 0.160279 & 0.251983 & 0.0700142 & 0.00231099 & 1 \\
\hline \multirow{2}{*}{ ODP } & LIB & 0.000459844 & 0.000670058 & 0.00538928 & 0.988606 & 0.000754 & 0.002189 & 0.000922 & 0.00101037 & 1 \\
\hline & LIPB & 0.000208354 & 0.00041961 & 0.00226714 & 0.991986 & 0.000626 & 0.002089 & 0.0013895 & 0.00101449 & 1 \\
\hline \multirow{2}{*}{ PMPF } & LIB & 0.004764352 & 0.029234524 & 0.133127403 & 0.391336 & 0.153662 & 0.134591 & 0.0419027 & 0.11138291 & 1 \\
\hline & LIPB & 0.002478183 & 0.027560396 & 0.059355356 & 0.448319 & 0.113744 & 0.147483 & 0.0724989 & 0.12856129 & 1 \\
\hline \multirow{2}{*}{ POFP } & LIB & 0.008032905 & 0.038113798 & 0.156022913 & 0.275686 & 0.11298 & 0.170266 & 0.0576542 & 0.18124425 & 1 \\
\hline & LIPB & 0.004066792 & 0.046182043 & 0.068862352 & 0.305947 & 0.092625 & 0.181595 & 0.0970891 & 0.20363233 & 1 \\
\hline \multirow{2}{*}{ TAP } & LIB & 0.003039946 & 0.018040327 & 0.102219738 & 0.524849 & 0.151519 & 0.08744 & 0.0257105 & 0.0871813 & 1 \\
\hline & LIPB & 0.001553859 & 0.018763943 & 0.044467548 & 0.592635 & 0.105794 & 0.094157 & 0.0437136 & 0.0989149 & 1 \\
\hline \multirow[b]{2}{*}{ TETP } & LIB & 0.001904767 & 0.045785865 & 0.341572889 & 0.13139 & 0.253538 & 0.096032 & 0.0641161 & 0.06566073 & 1 \\
\hline & LIPB & 0.001257997 & 0.032120549 & 0.187696596 & 0.187233 & 0.220976 & 0.133614 & 0.1408526 & 0.09624941 & 1 \\
\hline
\end{tabular}


Table A5. Numerical results of environmental assessment of batteries' production phase.

\begin{tabular}{|c|c|c|c|c|c|c|c|c|}
\hline \multicolumn{2}{|c|}{ ReCiPe Midpoint (H) } & \multirow{3}{*}{$\begin{array}{c}\text { Separator } \\
0.010887993 \\
0.005517578\end{array}$} & \multirow{3}{*}{$\begin{array}{c}\text { Cell Container } \\
0.044055236 \\
0.069473559\end{array}$} & \multirow{3}{*}{$\begin{array}{l}\text { Electrolyte } \\
0.194218874 \\
0.087832843\end{array}$} & \multirow{3}{*}{$\begin{array}{c}\text { Cathode } \\
0.31273 \\
0.347326\end{array}$} & \multirow{3}{*}{$\begin{array}{c}\text { Anode } \\
0.037773 \\
0.039531\end{array}$} & \multirow{3}{*}{$\begin{array}{c}\text { Assembly } \\
0.4003355 \\
0.450319\end{array}$} & \multirow{3}{*}{$\begin{array}{c}\text { Sum } \\
1 \\
1\end{array}$} \\
\hline & LIB & & & & & & & \\
\hline$G W$ & LIPB & & & & & & & \\
\hline \multirow{2}{*}{ FDP } & LIB & 0.018102357 & 0.047340107 & 0.262772897 & 0.17919 & 0.046714 & 0.4458804 & 1 \\
\hline & LIPB & 0.009233623 & 0.109280443 & 0.121120445 & 0.198473 & 0.057033 & 0.5048589 & 1 \\
\hline \multirow{2}{*}{ FETP } & LIB & 0.01034413 & 0.087965191 & 0.066646669 & 0.297423 & 0.530834 & 0.0067872 & 1 \\
\hline & LIPB & 0.006794049 & 0.062100777 & 0.037102067 & 0.42318 & 0.461023 & 0.009801 & 1 \\
\hline \multirow{2}{*}{ FEP } & LIB & 0.003413769 & 0.036200759 & 0.096278716 & 0.173025 & 0.689275 & 0.0018068 & 1 \\
\hline & LIPB & 0.002389698 & 0.030294906 & 0.056831011 & 0.264097 & 0.643648 & 0.0027397 & 1 \\
\hline \multirow{2}{*}{ HTP } & LIB & 0.001692794 & 0.024614773 & 0.106729763 & 0.123245 & 0.719548 & 0.0241698 & 1 \\
\hline & LIPB & 0.001219879 & 0.01930678 & 0.064336741 & 0.193792 & 0.682713 & 0.038632 & 1 \\
\hline \multirow{2}{*}{ METP } & LIB & 0.008213397 & 0.072897083 & 0.078433887 & 0.267323 & 0.562862 & 0.010271 & 1 \\
\hline & LIPB & 0.005486843 & 0.051615795 & 0.044019851 & 0.387532 & 0.496199 & 0.0151458 & 1 \\
\hline \multirow{2}{*}{ MEP } & LIB & 0.010718055 & 0.070956918 & 0.327890305 & 0.330604 & 0.202152 & 0.0576783 & 1 \\
\hline & LIPB & 0.006497288 & 0.12705838 & 0.17083936 & 0.436811 & 0.181442 & 0.0773518 & 1 \\
\hline \multirow{2}{*}{ MDP } & LIB & 0.000665164 & 0.030613921 & 0.024287598 & 0.610077 & 0.331467 & 0.0028895 & 1 \\
\hline & LIPB & 0.000361612 & 0.016876326 & 0.011147347 & 0.731807 & 0.236399 & 0.0034085 & 1 \\
\hline \multirow{2}{*}{ ODP } & LIB & 0.000461279 & 0.000672149 & 0.005406096 & 0.991691 & 0.000756 & 0.0010135 & 1 \\
\hline & LIPB & 0.000209082 & 0.000421075 & 0.002275054 & 0.995448 & 0.000628 & 0.001018 & 1 \\
\hline \multirow{2}{*}{ PMPF } & LIB & 0.005785446 & 0.035500055 & 0.161659212 & 0.475207 & 0.186594 & 0.1352544 & 1 \\
\hline & LIPB & 0.003177084 & 0.035333023 & 0.076094849 & 0.574754 & 0.145822 & 0.1648184 & 1 \\
\hline \multirow{2}{*}{ POFP } & LIB & 0.010404243 & 0.049365103 & 0.202081335 & 0.357069 & 0.146332 & 0.2347481 & 1 \\
\hline & LIPB & 0.005638019 & 0.064024721 & 0.095467689 & 0.424151 & 0.128412 & 0.2823068 & 1 \\
\hline \multirow{2}{*}{ TAP } & LIB & 0.003427804 & 0.020342045 & 0.115261685 & 0.591813 & 0.170851 & 0.0983045 & 1 \\
\hline & LIPB & 0.001802351 & 0.021764656 & 0.051578758 & 0.687409 & 0.122712 & 0.1147333 & 1 \\
\hline \multirow{2}{*}{ TETP } & LIB & 0.00226798 & 0.05451661 & 0.406706223 & 0.156444 & 0.301884 & 0.0781813 & 1 \\
\hline & LIPB & 0.001733893 & 0.044271634 & 0.258701527 & 0.258063 & 0.30457 & 0.1326602 & 1 \\
\hline
\end{tabular}

\section{References}

1. Gu, F.; Guo, J.; Yao, X.; Summers, P.A.; Widijatmoko, S.D.; Hall, P. An investigation of the current status of recycling spent lithium-ion batteries from consumer electronics in China. J. Clean. Prod. 2017, 161, 765-780. [CrossRef]

2. Peters, J.F.; Baumann, M.; Zimmermann, B.; Braun, J.; Weil, M. The environmental impact of Li-Ion batteries and the role of key parameters-A review. Renew. Sustain. Energy Rev. 2017, 67, 491-506. [CrossRef]

3. Bian, J.; Bai, H.; Li, W.; Yin, J.; Xu, H. Comparative environmental life cycle assessment of waste mobile phone recycling in China. J. Clean. Prod. 2016, 131, 209-218. [CrossRef]

4. Yazdani, P.; Chatterjee, M.; Montero-Simo, J.; Araque-Padilla, R.A. An Integrated Multi-Attribute Model for Evaluation of Sustainable Mobile Phone. Sustainability 2019, 11, 3704. [CrossRef]

5. Espinosa, N.; Garcíavalverde, R.; Krebs, F.C. Life-cycle analysis of product integrated polymer solar cells. Energy Environ. Sci. 2011, 4, 1547-1557. [CrossRef]

6. Liang, S.S.; Yan, W.; Wu, X.; Zhang, Y.; Zhu, Y.; Wang, H. Gel polymer electrolytes for lithium-ion batteries: Fabrication, characterization and performance. Solid State Ion. 2017, 318, 2-18. [CrossRef]

7. Singh, S.K.; Balo, L.; Gupta, H.; Singh, V.K.; Tripathi, A.K.; Verma, Y.L.; Singh, R.K. Improved electrochemical performance of EMIMFSI ionic liquid based gel polymer electrolyte with temperature for rechargeable lithium battery. Energy 2018, 150, 890-900. [CrossRef]

8. Sen, B.; Onat, N.C.; Kucukvar, M.; Tatari, O. Material footprint of electric vehicles: A multiregional life cycle assessment. J. Clean. Prod. 2019, 209, 1033-1043. [CrossRef]

9. Bakas, I.; Fischer, C.; Haselsteiner, S.; McKinnon, D.; Milios, L.; Harding, A.; Wittmer, D. Present and Potential Future Recycling of Critical Metals in WEEE. 2014. Available online: https://epub.wupperinst.org/frontdoor/ deliver/index/docId/5687/file/5687_WEEE.pdf (accessed on 1 May 2018).

10. Soo, V.K.; Doolan, M. Recycling mobile phone impact on life cycle assessment. Procedia CIRP 2014, 15, 263-271. [CrossRef]

11. Elduque, D.; Javierre, C.; Pina, C.; Martinez, E.; Jimenez, E. Life cycle assessment of a domestic induction hob: Electronic boards. J. Clean. Prod. 2014, 76, 74-84. [CrossRef] 
12. Rubin, R.S.; de Castro, M.A.S.; Brandão, D.; Schalch, V.; Ometto, A.R. Utilization of Life Cycle Assessment methodology to compare two strategies for recovery of copper from printed circuit board scrap. J. Clean. Prod. 2014, 64, 297-305. [CrossRef]

13. GU, F.; GUO, J.; HALL, P.; GU, X. An integrated architecture for implementing Extended Producer Responsibility in the context of Industry 4.0. Int. J. Prod. Res. 2019, 57, 1458-1477. [CrossRef]

14. Gu, F.; Zheng, Y.; Zhang, W.; Yao, X.; Pan, D.; Wong, A.S.M.; Sharmin, N. Can bamboo fibres be an alternative to flax fibres as materials for plastic reinforcement? A comparative life cycle study on polypropylene/flax/bamboo laminates. Ind. Crops Prod. 2018, 121, 372-387. [CrossRef]

15. Lv, J.; Gu, F.; Zhang, W.; Guo, J. Life cycle assessment and life cycle costing of sanitary ware manufacturing: A case study in China. J. Clean. Prod. 2019, 238, 117938. [CrossRef]

16. ISO. International Organization for Standardization. 14040 Series: Environmental Management-Life Cycle Assessment-Principles and Framework; ISO: Geneva, Switzerland, 2006.

17. Vandepaer, V.; Cloutier, J.; Amor, B. Environmental impacts of lithium metal polymer and lithium-ion stationary batteries. Renew. Sustain. Energy Rev. 2017, 78, 46-60. [CrossRef]

18. Hiremath, M.; Derendorf, K.; Vogt, T. Comparative Life Cycle Assessment of Battery Storage Systems for Stationary Applications. Environ. Sci. Technol. 2015, 49, 825-4833. [CrossRef] [PubMed]

19. Bobba, S.; Mathieux, F.; Ardentea, F.; Blengini, G.A.; Cusenza, M.A.; Podias, A.; Pfrang, A. Life Cycle Assessment of repurposed electric vehicle batteries: An adapted method based on modelling energy flows. J. Energy Storage 2018, 19, 213-225. [CrossRef]

20. Ahmadi, L.; Young, S.B.; Fowler, M.; Fraser, R.A.; Achachlouei, M.A. A cascaded life cycle: Reuse of electric vehicle lithium-ion battery packs in energy storage systems. Int. J. Life Cycle Assess. 2017, 22, 111-124. [CrossRef]

21. Hao, H.; Mu, Z.; Jiang, S.; Liu, Z.; Zhao, F. GHG Emissions from the production of lithium-ion batteries for electric vehicles in China. Sustainability 2017, 9, 504. [CrossRef]

22. JD.com Announces Fourth Quarter and Full Year 2017 Results. 2018. Available online: http://ir.jd.com/ phoenix.zhtml?c=253315\&p=irol-newsArticle_pf\&ID=2335867 (accessed on 1 May 2018).

23. Notter, D.A.; Gauch, M.; Widmer, R.; Wager, P.; Stamp, A.; Zah, R.; Althaus, H.J. Contribution of Li-ion batteries to the environmental impact of electric vehicles. Environ. Sci. Technol. 2010, 44, 6550-6556. [CrossRef]

24. Majeau-Bettez, G.; Hawkins, T.R.; Strømman, A.H. Life cycle environmental assessment of lithium-ion and nickel metal hydride batteries for plug-in hybrid and battery electric vehicles. Environ. Sci. Technol. 2011, 45, 4548-4554. [CrossRef] [PubMed]

25. Wang, Q.; Liu, W.; Yuan, X.; Tang, H.; Tang, Y.; Wang, M.; Zuo, J.; Song, Z.; Sun, J. Environmental impact analysis and process optimization of batteries based on life cycle assessment. J. Clean. Prod. 2018, 174, 1262-1273. [CrossRef]

26. Xie, Y.; Yu, H.; Ou, Y.; Li, C. Environmental impact assessment of recycling waste traction battery. Inorg. Chem. Ind. 2015, 47, 43-46.

27. Hao, H.; Qiao, Q.; Liu, Z.; Zhao, F. Impact of recycling on energy consumption and greenhouse gas emissions from electric vehicle production: The China 2025 case. Resour. Conserv. Recycl. 2017, 122, 114-125. [CrossRef]

28. Ghosh, B.; Ghosh, M.K.; Parhi, P.; Mukherjee, P.K.; Mishra, B.K. Waste printed circuit boards recycling: An extensive assessment of current status. J. Clean. Prod. 2015, 94, 5-19. [CrossRef]

29. Zhou, D.; Shanmukaraj, D.; Tkacheva, A.; Armand, M.; Wang, G. Polymer Electrolytes for Lithium-Based Batteries: Advances and Prospects. Chem 2019, 5, 2326-2352. [CrossRef]

30. Mathieu, R.; Baghdadi, I.; Briat, O.; Gyan, P.; Vinassa, J.M. D-optimal design of experiments applied to lithium battery for ageing model calibration. Energy 2017, 141, 2108-2119. [CrossRef]

31. Uddin, K.; Dubarry, M.; Glick, M.M.B. The viability of vehicle-to-grid operations from a battery technology and policy perspective. Energy Policy 2018, 113, 342-347. [CrossRef]

32. Richa, K.; Babbitt, C.W.; Gaustad, G.; Wang, X. A future perspective on lithium-ion battery waste flows from electric vehicles. Resour. Conserv. Recycl. 2014, 83, 63-76. [CrossRef]

33. Faria, R.; Marques, P.; Garcia, R.; Moura, P.; Freire, F.; Delgado, J.; de Almeida, A.T. Primary and secondary use of electric mobility batteries from a life cycle perspective. J. Power Sources 2014, 262, 169-177. [CrossRef]

34. Li, J.; Xu, Z. Environmental friendly automatic line for recovering metal from waste printed circuit boards. Environ. Sci. Technol. 2010, 44, 1418-1423. [CrossRef] [PubMed]

35. Schrynmakers, P.D. Life cycle thinking in the aluminium industry. Int. J. Life Cycle Assess. 2009, 14, 2-5. [CrossRef] 
36. McManus, M.C. Environmental consequences of the use of batteries in low carbon systems: The impact of battery production. Appl. Energy 2012, 93, 288-295. [CrossRef]

37. Ellingsen, L.A.W.; Majeau-Bettez, G.; Singh, B.; Srivastava, A.K.; Valøen, L.O.; Strømman, A.H. Life cycle assessment of a lithium-ion battery vehicle pack. J. Ind. Ecol. 2014, 18, 113-124. [CrossRef]

38. Peters, J.F.; Weil, M. Providing a common base for life cycle assessments of Li-Ion batteries. J. Clean. Prod. 2018, 171, 704-713. [CrossRef]

39. Hawkins, T.R.; Singh, B.; Majeau-Bettez, G.; Strømman, A.H. Comparative environmental life cycle assessment of conventional and electric vehicles. J. Ind. Ecol. 2013, 17, 53-64. [CrossRef]

40. Hou, J.; Teo, T.; Zhou, F.; Ming, K.; Chen, H. Does industrial green transformation successfully facilitate a decrease in carbon intensity in china? an environmental regulation perspective. J. Clean. Prod. 2018, 184, 1060-1071. [CrossRef]

41. Komiyama, R.; Fujii, Y. Assessment of massive integration of photovoltaic system considering rechargeable battery in Japan with high time-resolution optimal power generation mix model. Energy Policy 2014, 66, 73-89. [CrossRef]

42. Yuan, J.; Na, C.; Lei, Q.; Xiong, M.; Guo, J.; Hu, Z. Coal use for power generation in China. Resour. Conserv. Recycl. 2018, 129, 443-453. [CrossRef]

43. Deng, Y.; Li, J.; Li, T.; Gao, X.; Yuan, C. Life cycle assessment of lithium sulfur battery for electric vehicles. J. Power Sources 2017, 343, 284-295. [CrossRef]

44. Deng, Y.; Li, J.; Li, T.; Zhang, J.; Yang, F.; Yuan, C. Life cycle assessment of high capacity molybdenum disulfide lithium-ion battery for electric vehicles. Energy 2017, 123, 77-88. [CrossRef]

45. Yang, H.; Guo, C.; Naveed, A.; Lei, J.; Yang, J.; Nuli, Y.; Wang, J. Recent progress and perspective on lithium metal anode protection. Energy Storage Mater. 2018, 14, 199-221. [CrossRef]

46. Cheung, G.; Davies, P.J. In the transformation of energy systems: What is holding australia back? Energy Policy 2017, 109, 96-108. [CrossRef]

47. Troy, S.; Schreiber, A.; Reppert, T.; Gehrke, H.G.; Finsterbusch, M.; Uhlenbruck, S.; Stenzel, P. Life cycle assessment and resource analysis of all-solid-state batteries. Appl. Energy 2016, 169, 757-767. [CrossRef]

48. Ziemann, S.; Weil, M.; Schebek, L. Tracing the fate of lithium--The development of a material flow model. Resour. Conserv. Recycl. 2012, 63, 26-34. [CrossRef]

49. Hao, H.; Liu, Z.; Zhao, F.; Geng, Y.; Sarkis, J. Material flow analysis of lithium in china. Resour. Policy 2017, 51, 100-106. [CrossRef]

50. Mo, J.; Jeon, W. The impact of electric vehicle demand and battery recycling on price dynamics of lithium-ion battery cathode materials: A vector error correction model (VECM) analysis. Sustainability 2018, 10, 2870. [CrossRef]

51. Mudd, G.M.; Weng, Z.; Jowitt, S.M.; Turnbull, I.D.; Graede, T.E. Quantifying the recoverable resources of by-product metals: The case of cobalt. Ore Geol. Rev. 2013, 55, 87-98. [CrossRef]

52. Zeng, X.; Li, J.; Liu, L. Solving spent lithium-ion battery problems in China: Opportunities and challenges. Renew. Sustain. Energy Rev. 2015, 52, 1759-1767. [CrossRef]

53. Zeng, X.; Li, J. On the sustainability of cobalt utilization in China. Resour. Conserv. Recycl. 2015, 104, 12-18. [CrossRef]

54. Zubi, G.; Dufo-López, R.; Carvalho, M.; Pasaoglu, G. The lithium-ion battery: State of the art and future perspectives. Renew. Sustain. Energy Rev. 2018, 89, 292-308. [CrossRef]

55. Few, S.; Schmidt, O.; Offer, G.J.; Brandon, N.; Nelson, J.; Gambhir, A. Prospective improvements in cost and cycle life of off-grid lithium-ion battery packs: An analysis informed by expert elicitations. Energy Policy 2018, 114, 578-590. [CrossRef]

56. Xin, S.; Chang, Z.; Zhang, X.; Guo, Y. Progress of rechargeable lithium metal batteries based on conversion reactions. Natl. Sci. Rev. 2017, 4, 54-70. [CrossRef]

57. Yang, F.; Wang, D.; Zhao, Y.; Tsui, K.L.; Bae, S.J. A study of the relationship between coulombic efficiency and capacity degradation of commercial lithium-ion batteries. Energy 2018, 145, 486-495. [CrossRef]

58. Gu, F.; Zhang, W.; Guo, J.; Hall, P. Exploring “Internet+Recycling”: Mass balance and life cycle assessment of a waste management system associated with a mobile application. Sci. Total Environ. 2019, 649, 172-185. [CrossRef]

(C) 2019 by the authors. Licensee MDPI, Basel, Switzerland. This article is an open access article distributed under the terms and conditions of the Creative Commons Attribution (CC BY) license (http://creativecommons.org/licenses/by/4.0/). 